\title{
Microseismicity and stress in the vicinity of the Alpine Fault, central Southern Alps, New Zealand
}

\author{
C. M. Boese, ${ }^{1}$ J. Townend, ${ }^{1}$ E. Smith, ${ }^{1}$ and T. Stern ${ }^{1}$ \\ Received 18 April 2011; revised 29 November 2011; accepted 8 December 2011; published 8 February 2012.
}

[1] We investigate present-day microseismicity associated with the central Alpine Fault and the zone of active deformation and uplift in the central Southern Alps.

Using 14 months of data, robust hypocenter locations have been obtained for $\sim 1800$ earthquakes of magnitudes between -0.3 and 4.2. We derived a magnitude scale with a frequency-dependent attenuation factor, $\gamma(\mathrm{f})=\gamma_{0} \mathrm{f}$, where $\gamma_{0}=1.89 \pm 0.02 \times 10^{-3} \mathrm{~s} / \mathrm{km}$, that enables magnitudes to be calculated consistently for earthquakes of different sizes and frequency contents. The maximum depth of the seismicity varies systematically with distance from the Alpine Fault, from $10 \pm 2 \mathrm{~km}$ near the fault to $8 \pm 2 \mathrm{~km}$ within $20 \mathrm{~km}$ and $15 \pm 2 \mathrm{~km}$ further southeast. This distribution correlates with lateral variations in crustal resistivity: earthquake hypocenters are concentrated in areas of strong resistivity gradients and restricted to depths of resistivities $>100 \Omega \mathrm{m}$. Rocks at greater depth are too hot, too fluid-saturated, or too weak to produce detectable earthquakes. Focal mechanism solutions computed for 211 earthquakes $\left(\mathrm{M}_{\mathrm{L}}>0.44\right)$ exhibit predominantly strike-slip mechanisms. We obtain a maximum horizontal compressive stress direction of $115 \pm 10^{\circ}$ from focal mechanism inversion. This azimuth is consistent with findings from elsewhere in the central and northern South Island, and indicates a uniform crustal stress field despite pronounced variations in crustal structure and topographic relief. Our stress estimates suggest that the Alpine Fault (with a mean strike of $055^{\circ}$ ) is poorly oriented in an Andersonian sense but that individual thrust and strike-slip segments of the fault's surface trace have close to optimal orientations.

Citation: Boese, C. M., J. Townend, E. Smith, and T. Stern (2012), Microseismicity and stress in the vicinity of the Alpine Fault, central Southern Alps, New Zealand, J. Geophys. Res., 117, B02302, doi:10.1029/2011JB008460.

\section{Introduction}

[2] The Alpine Fault is the principal active structure accommodating Australia-Pacific relative plate motion in the central South Island of New Zealand [Norris and Cooper, 2001], where it forms the western boundary of the Southern Alps orogen [Norris et al., 1990]. The fault's dextral-reverse kinematics involve high rates of hanging wall uplift (6$9 \mathrm{~mm} / \mathrm{yr}$ from GPS measurements [Beavan et al., 2004, 2010] and up to $12 \mathrm{~mm} / \mathrm{yr}$ inferred from geological measurements [Norris and Cooper, 2001, and references therein]) which have resulted in the exhumation of mid-crustal rocks from depths of 20-30 km in <5 Myr [Kamp et al., 1989; Cooper, 1980; Little et al., 2002; Norris and Cooper, 2003]. This setting makes the central section of the Alpine Fault a site of global importance for research into the evolution and mechanics of large active faults and the conditions under which earthquakes occur [e.g., Sibson et al., 1979; Koons, 1987; Stern et al., 2001; Cox and Sutherland, 2007].

\footnotetext{
${ }^{1}$ School of Geography, Environment and Earth Science, Victoria University of Wellington, Wellington, New Zealand.

Copyright 2012 by the American Geophysical Union. 0148-0227/12/2011JB008460
}

[3] Despite horizontal slip rates of $21-27 \mathrm{~mm} / \mathrm{yr}$ [Wellman, 1953; Norris and Cooper, 2001; Sutherland et al., 2006] and paleoseismic evidence for $\mathrm{M}_{\mathrm{W}} \sim 7.9$ earthquakes every 200-400 years on the central portion of the Alpine Fault [Adams, 1980; Wells et al., 1999; Wells and Goff, 2007; Sutherland et al., 2007], and the most recent event in 1717 C.E., no large earthquakes [Evison, 1971; Anderson and Webb, 1994] or measurable creep [Evison, 1971; Beavan et al., 1999; Sutherland et al., 2007, and references therein] have been observed historically on the Alpine Fault [Evison, 1971; Anderson and Webb, 1994; Sutherland et al., 2007]. The region as a whole exhibits particularly low levels of seismicity above magnitude $\mathrm{M}_{\mathrm{L}} 2$ and a shallow $(<12 \mathrm{~km})$ brittle-ductile transition zone [Leitner et al., 2001]. Unlike other major continental transform faults (e.g. San Andreas Fault, North Anatolian Fault, Dead Sea Transform Fault and the Denali Fault) the Alpine Fault has not produced a large earthquake in historic times and is inferred to be late in its earthquake cycle. This fault affords the opportunity to study continental faulting processes and conditions in the seismogenic crust before an anticipated large earthquake [Townend et al., 2009].

[4] The purpose of this study is to detect, locate and characterize small earthquakes occurring on and adjacent to 


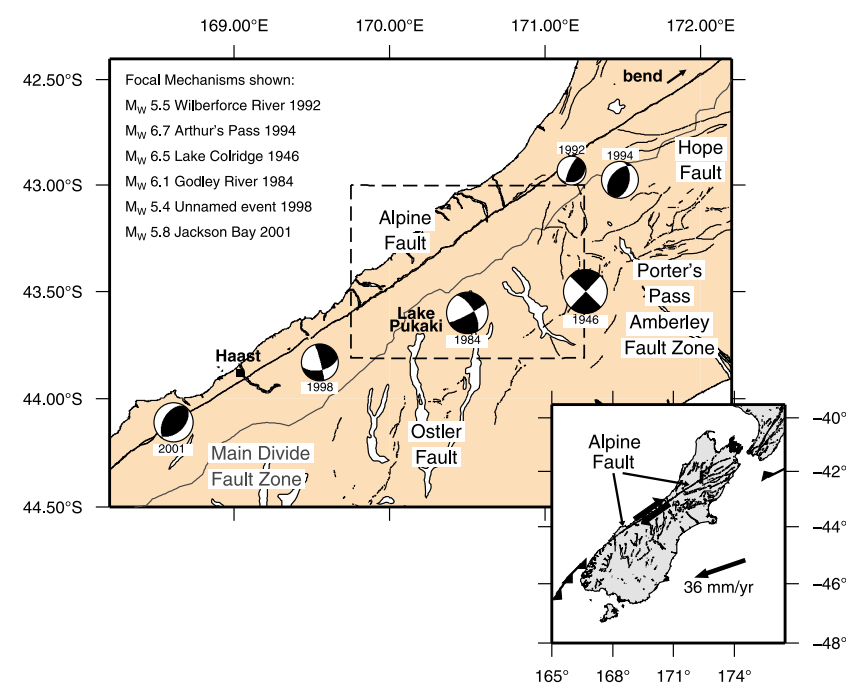

Figure 1. Major faults and focal mechanism solutions for the six largest, more recent events in and adjacent to the study area (dashed rectangle) since 1946 (Table 1) in the central South Island of New Zealand. All focal mechanism solutions are lower-hemisphere projections of the focal sphere. Displayed faults are from the Active Faults Database by the Institute of Geological and Nuclear Science Limited, New Zealand. The inset map shows the tectonic setting of the Alpine Fault.

the central Alpine Fault, using short-period seismometers deployed in shallow boreholes. We have analyzed 14 months of microseismicity data from the central Southern Alps region and obtained precise hypocenter locations, magnitudes and focal mechanisms solutions which we use to determine the prevailing state of tectonic stress and the thickness of the seismogenic zone beneath the Southern Alps. We discuss seismically active and inactive regions and interpret the distribution of seismicity in conjunction with crustal resistivity data.

\subsection{Tectonic Setting and Characteristics of the Study Area}

[5] The Alpine Fault is a continental transform fault that links the west-dipping Hikurangi subduction zone beneath the northern South Island with the east-dipping Puysegur subduction zone in the south [Berryman et al., 1992] (Figure 1, inset). The average strike of the Alpine Fault is $055^{\circ}$ at an angle of $18^{\circ}$ to the Pacific-Australia relative plate motion vector [De Mets et al., 1994]. The fault's orientation varies between steeply dipping north of the Alpine Fault bend (approximately $-42.17^{\circ} / 172.18^{\circ}$ ) to eastward dipping at $45^{\circ}$ to $60^{\circ}$ [Sibson et al., 1981; Stern et al., 2007] in the central Southern Alps and steeply dipping to the southeast south of Haast [e.g., Sutherland et al., 2007] (Figure 1). A change from predominantly strike-slip in the northern and southern section to dextral-reverse motion takes place on the central portion of the Alpine Fault. In the central South Island, the fault accommodates about $75 \%$ of the strike-slip component of the relative plate motion and up to $100 \%$ of the convergence [Norris and Cooper, 2001]. The Southern Alps are the result of the oblique continental collision between the Australian and Pacific plates during the last 10 Myr [Walcott, 1998; Cande and Stock, 2004].

[6] In the northernmost South Island, several steeply dipping, active strike-slip faults, known collectively as the Marlborough Fault System [Little and Jones, 1998], accommodate the entire strike-slip component of the plate motion. The youngest and southernmost Marlborough fault is the Hope Fault with a slip-rate of $23 \pm 4 \mathrm{~mm} / \mathrm{a}$ [Langridge et al., 2003]. About $60 \mathrm{~km}$ to the south, the Porter's PassAmberley Fault Zone, a $40 \mathrm{~km}$ long continuous fault and a number of smaller fault segments, is thought to be the incipient continuation of the Marlborough Fault System to the south [Cowan et al., 1996] (Figure 1). The Marlborough faults have produced three large earthquakes $(\mathrm{M}>7)$ since 1840 [Grapes et al., 1998; Cowan, 1991; Doser et al., 1999; Berryman and Villamor, 2004]. Notably seismically active is the region where the Hope Fault merges with the Alpine Fault. Seven earthquakes of $\mathrm{M}_{\mathrm{W}}>5.4$ have occurred in this zone of high deformation since 1888 [e.g., Rynn and Scholz, 1978; Árnadóttir et al., 1995] (Table 1). These events exhibited a mixture of strike-slip and reverse focal mechanisms [Doser et al., 1999]. The two most recent earthquakes in this region were shallow reverse-faulting events [Abercrombie et al., 2000], the $\mathrm{M}_{\mathrm{W}} 6.7$ Arthur's Pass earthquake in 1994 [Robinson and McGinty, 2000] followed by the $1995 \mathrm{M}_{\mathrm{W}} 6.2$ Cass earthquake $30 \mathrm{~km}$ to the east

Table 1. Earthquakes of $M_{\mathrm{W}}>5.4$ and Their Focal Mechanism Solutions in the Central South Island ${ }^{\mathrm{a}}$

\begin{tabular}{|c|c|c|c|c|c|c|c|c|c|c|}
\hline Earthquake & Date & $\mathrm{M}_{\mathrm{W}}$ & $\begin{array}{l}\text { Latitude } \\
\text { (deg) }\end{array}$ & $\begin{array}{l}\text { Longitude } \\
\text { (deg) }\end{array}$ & $\begin{array}{l}\text { Depth } \\
(\mathrm{km})\end{array}$ & $\begin{array}{l}\text { Strike } \\
\text { (deg) }\end{array}$ & $\begin{array}{l}\text { Dip } \\
\text { (deg) }\end{array}$ & $\begin{array}{l}\text { Rake } \\
\text { (deg) }\end{array}$ & $\begin{array}{l}\text { Distance } \\
(\mathrm{km})\end{array}$ & Reference \\
\hline Glynn Wye & 1 Sep 1888 & 7.3 & -42.63 & 172.41 & $15 \pm 5$ & $75 \pm 20$ & $90 \pm 20$ & $-180 \pm 20$ & - & Hincapie et al. [2005] \\
\hline Arthur's Pass & 9 Mar 1929 & 7.0 & -42.79 & 171.93 & $11 \pm 5$ & $65 \pm 7$ & $90 \pm 20$ & $-178 \pm 10$ & - & Doser et al. [1999] \\
\hline Lake Coleridge & 26 Jun 1946 & 6.5 & -43.46 & 171.26 & $9 \pm 4$ & $44 \pm 17$ & $89 \pm 8$ & $180 \pm 13$ & $55.5^{\mathrm{b}}$ & Doser et al. [1999] \\
\hline Jackson Bay & 13 Oct 1947 & 6.2 & -44.42 & 168.48 & $18 \pm 2$ & $26 \pm 25$ & $46 \pm 18$ & $43 \pm 32$ & 22.6 & Doser et al. [1999] \\
\hline Godley River & 24 Jun 1984 & 6.1 & -43.60 & 170.56 & $13_{-3}^{+2}$ & $62_{-12}^{+5}$ & $83_{-5}^{+10}$ & $-154 \pm 5$ & $40.2^{\mathrm{b}}$ & Anderson et al. [1993] \\
\hline Wilberforce River & 30 Mar 1992 & 5.5 & -43.04 & 171.23 & 5 & 70 & 19 & 134 & $17.6^{\mathrm{b}}$ & Doser et al. [1999] \\
\hline Arthur's Pass & 18 Jun 1994 & 6.7 & -42.98 & 171.48 & $5 \pm 1$ & $221_{-10}^{+5}$ & $47 \pm 5$ & $112_{-10}^{+5}$ & $24.4^{\mathrm{b}}$ & Abercrombie et al. [2000] \\
\hline Aftershock AP & 19 Jun 1994 & 5.9 & -43.16 & 171.52 & $8_{-4}^{+1}$ & $253 \pm 15$ & $87_{-10}^{+5}$ & $178_{-20}^{+10}$ & 42.7 & Abercrombie et al. [2000] \\
\hline Unnamed event & 29 Mai 1995 & 5.5 & -42.96 & 171.50 & 15 & 53 & 67 & 174 & 24.0 & Doser et al. [1999] \\
\hline Cass & 24 Nov 1995 & 6.2 & -42.96 & 171.83 & 9 & $176 \pm 10$ & $46 \pm 5$ & $44 \pm 10$ & 37.0 & Gledhill et al. [2000] \\
\hline Unnamed event & 20 Oct 1998 & 5.4 & -43.83 & 169.55 & 12 & 78 & 54 & -175 & $14.3^{\mathrm{b}}$ & Dziewonski et al. [1999] \\
\hline Jackson Bay & 7 Dec 2001 & 5.8 & -44.17 & 168.71 & 7 & 48 & 45 & 103 & $10.1^{\mathrm{b}}$ & McGinty et al. [2005] \\
\hline
\end{tabular}

${ }^{a}$ Uncertainties are provided when known. For some recent events, the distance to the surface trace of the Alpine Fault was determined by projecting the earthquakes on a plane perpendicular to the fault (striking at an azimuth of $145^{\circ}$ ).

${ }^{\mathrm{b}}$ Events plotted in Figures 1 and 5 . 
Table 2. 1-D Velocity Models for the Central Southern Alps in Comparison $^{\mathrm{a}}$

\begin{tabular}{lccc}
\hline & \multicolumn{3}{c}{ Velocity $(\mathrm{km} / \mathrm{s})$} \\
\cline { 2 - 4 } Depth $(\mathrm{km})$ & Leitner et al. [2001] & O'Keefe [2008] & This Study \\
\hline-2 & & 3.50 & 5.67 \\
0 & 6.0 & 5.67 & \\
8 & & 5.79 & 5.79 \\
18 & 6.3 & 6.28 & 6.28 \\
35 & 7.2 & 7.35 & 7.35 \\
40 & 8.0 & 8.00 & 8.00 \\
\hline
\end{tabular}

${ }^{a}$ Note that not all models have the same depth boundaries, so the velocity column is blank if there is no such depth boundary in the model.

[Gledhill et al., 2000]. The largest aftershocks of the Arthur's Pass earthquake exhibited strike-slip mechanisms [Abercrombie et al., 2000; Doser et al., 1999].

[7] The largest recorded events in the central Southern Alps are the $1946 \mathrm{M}_{\mathrm{W}} 6.5$ Lake Coleridge [Doser et al., 1999] and the $1984 \mathrm{M}_{\mathrm{W}} 6.1$ Godley River [Anderson et al., 1993] earthquakes (Figure 1 and Table 1). Both strike-slip events occurred southeast of the Alpine Fault, at distances of 40 and $55 \mathrm{~km}$ from the surface trace. These earthquakes have similar strike directions and steeply dipping fault planes. Anderson et al. [1993] favored the northeast-striking fault plane undergoing right-lateral strike-slip as the rupture plane of the Godley River earthquake, a fault geometry similar to that of the Porter's Pass-Amberley Fault Zone to the northeast.

[8] The deformation zone adjacent to the central section of the Alpine Fault is narrowest in width $(80 \mathrm{~km}$ versus $200 \mathrm{~km}$ in the northern and southern part of South Island). Elevated temperatures at shallow depths are inferred from high erosion rates, high surface heat flow [Townend, 1999; Toy et al., 2010] and temperature modeling [Koons, 1987; Shi et al., 1996]. Comprehensive studies of the crustal and upper mantle structure in the central section of the Southern Alps during the SIGHT (South Island Geophysical Transect) project in 1996 and 1998 [Davey et al., 1998; Okaya et al., 2002] resulted in 2-D models of the seismic velocity for transect 1 [Van Avendonk et al., 2004] and 2 [Scherwath et al., 2003] and the resistivity structure along profile 1 [Wannamaker et al., 2002] across the Southern Alps orogen. These show a low-velocity zone at depths of 6-30 km in which P-wave speeds are reduced by $10 \%$ [Stern et al., 2001] coinciding with a U-shaped low-resistivity region $(<100$ $\Omega \mathrm{m})$, centered at $20 \mathrm{~km}$ depth and terminating at $10 \mathrm{~km}$ depth [Wannamaker et al., 2002]. Large volumes of fluids released from metamorphic processes and trapped below the brittleductile transition zone have been suggested as the cause of both the velocity and resistivity anomalies [Wannamaker et al., 2002]. Vry et al. [2009] showed that such fluids can be generated by the alteration of epidote to plagioclase in typical Alpine Schist. This is only possible in a narrow temperature range $\left(400-560^{\circ} \mathrm{C}\right)$ associated with the fast exhumation of rock and near-isothermal decompression.

[9] At the southern limit of the central Alpine Fault, two large events occurred at distances of 14 and $3-10 \mathrm{~km}$, respectively, southeast of the surface trace of the Alpine Fault in 1998 and 2001 (Figure 1 and Table 1). The 1998 $\mathrm{M}_{\mathrm{W}} 5.4$ earthquake has not yet been studied in detail. The CMT focal mechanism solution [Dziewonski et al., 1999] gives a strike-slip mechanism but the solution is poorly constrained. The $2001 \mathrm{M}_{\mathrm{W}} 5.8$ Jackson Bay earthquake [McGinty et al., 2005] was a shallow thrust earthquake with no surface rupture. The aftershock distribution exhibited clustered events $5 \mathrm{~km}$ to the southeast of the Alpine Fault. McGinty et al. [2005] obtained a variety of focal mechanism solutions for the aftershocks with predominantly strike-slip faulting. Further south of Jackson Bay, a $\mathrm{M}_{\mathrm{W}} 6.2$ event in 1947 exhibited an oblique-reverse mechanism [Doser et al., 1999] (Table 1).

\subsection{Previous Seismicity Studies}

[10] Reyners [1988] described the seismicity recorded by the nine stations of the Lake Pukaki network between 1975 and 1983, before, during and after the impounding of Lake Pukaki, $40 \mathrm{~km}$ southwest of the center of our study area (Figure 1). The catalogue of events was complete to $M_{L}$ 1.8 with hypocentral errors of $3-5 \mathrm{~km}$. A small proportion (1-2\%) of all earthquakes occurred at depths greater than $15 \mathrm{~km}$ and $65 \%$ of all earthquakes were located between 5 and $9 \mathrm{~km}$ depth.

[11] Leitner et al. [2001] investigated the long-term regional seismicity of the Southern Alps using data from the Southern Alps Passive Seismic Experiment (SAPSE) network, the New Zealand National Station Network, the Lake Pukaki array and the temporary Mount Cook aftershock deployment. That study reported 5491 earthquake locations with magnitudes of $2 \leq \mathrm{M}_{\mathrm{L}} \leq 4.2$ and 53 well-constrained focal mechanisms. A simultaneous inversion to determine hypocenter locations and P-wave velocity structure was carried out using a subset of 195 earthquakes (Table 2). A uniform seismogenic depth of $12 \pm 2 \mathrm{~km}$ for central South Island was observed, except for a shallower depth of 8-9 km beneath the highest topography of the Alps. Leitner et al. [2001] describe a gap in the seismicity noted previously [Eiby, 1971; Evison, 1971; Scholz et al., 1973; Caldwell and Frohlich, 1975; Eberhart-Phillips, 1995] as a triangular section between the Wanganui River and Franz Josef. Wellconstrained focal mechanisms beneath the central Southern Alps exhibited oblique strike-slip and thrust mechanisms, as well as two normal-faulting mechanisms which were inferred by the authors to have been hydrologically triggered. The latter were derived from a swarm of events following severe rainfall and flooding (102 $\mathrm{mm}$ of rain in $32 \mathrm{~h}$ ) in mid-December 1995 [Leitner et al., 2001].

[12] Prior to this study, a temporary seismic network was installed between the Wanganui River and Fox Glacier by O'Keefe [2008] between September 2006 and March 2007. O'Keefe [2008] obtained a 1-D velocity model from a simultaneous inversion of earthquake hypocenters and velocity structure of 411 events in the central Southern Alps (Table 2). These events indicate a maximum seismogenic depth of $15 \mathrm{~km}$ for the region and $10 \mathrm{~km}$ near Fox Glacier. A "horseshoe" pattern was observed in the seismicity distribution for earthquakes above the cut-off magnitude of $\mathrm{M}_{\mathrm{L}}$ 1.6. O'Keefe [2008] derived a magnitude scale for the central Southern Alps region with an attenuation parameter of $1.69 \times 10^{-2} \mathrm{~km}^{-1}, 2.5$-times higher than the value used in routine magnitude determination for earthquakes in New Zealand [e.g., Ristau, 2009]. This suggests that attenuation is underestimated during routine magnitude determination for shallow local events in the central Southern Alps. 


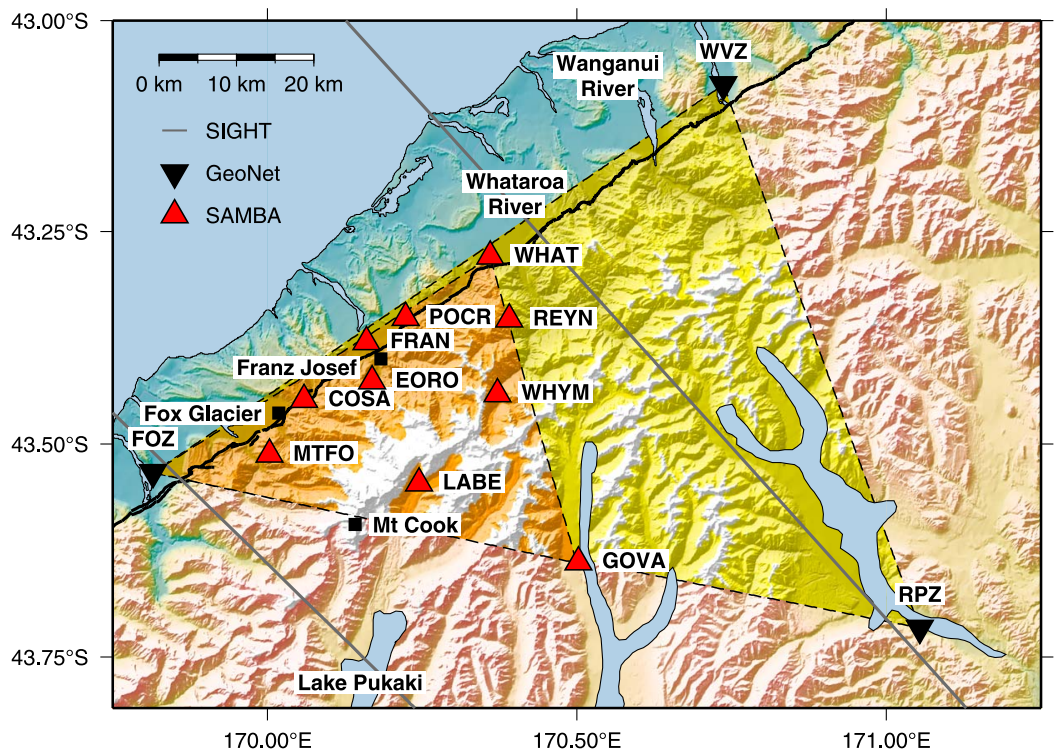

Figure 2. The Southern Alps Microearthquake Borehole Array (SAMBA, red) and the GeoNet station network (black) in the study area. The earthquake location quality with regard to the station distribution is discussed in the text for orange and yellow marked areas. Grey lines indicate two transects of the SIGHT project [Davey et al., 1998; Okaya et al., 2002] for which 2-D velocity models and a resistivity model (northern transect, see Figure 5) exist.

\subsection{Station Array and Data Analysis}

[13] The Southern Alps Microearthquake Borehole Array (SAMBA) of ten short-period seismometers was established between November 2008 and June 2009 (Figure 2 and Table A1). Three of the instruments are located in boreholes of 46, 61 and $98 \mathrm{~m}$ depths, whereas the remaining sensors are at shallow depths of 1-2 m. The SAMBA network has a station spacing of approximately $8 \mathrm{~km}$ along strike on either side of the Alpine Fault and $<16 \mathrm{~km}$ perpendicular to the fault. This geometry allows for accurate depth estimates for events located within the SAMBA station network (orange triangle in Figure 2). Accurate epicenters with somewhat larger depth uncertainties can be obtained within a region bounded by the three stations of the permanent GeoNet network (yellow area in Figure 2). These broadband stations have been operated by GeoNet as part of the national station network since 1990 [Anderson and Webb, 1994; Petersen et al., 2011].

[14] The SAMBA stations are equipped with 2 or $4.5 \mathrm{~Hz}$ GeoSpace Technologies HS-1-LT three-component shortperiod seismometers, which record at a sampling rate of $200 \mathrm{~Hz}$ on high gain. The three deepest borehole stations were temporarily augmented with Mark Products L-4C3D seismometers of $1 \mathrm{~Hz}$ natural frequency at the surface for three months. The continuous data are scanned for events using a triggering routine that compares short-term and longterm averages in $0.5 \mathrm{~s}$ and $10 \mathrm{~s}$ data windows, respectively. The arrival-times of the P- and S-wave of all recorded earthquakes have been identified manually using SEISAN [Havskov and Ottemöller, 2000]. Weights of between 0 (highest) and 4 (lowest quality) are assigned to individual phases according to their distinctiveness from the background noise level. Station COSA lost satellite contact for 77 days during June and August 2009 resulting in uncertain absolute arrival-times. Consequently, a weight of 9 is assigned, which enables the use of differential arrival-times, $t_{S}-t_{P}$, for COSA in the location process.

\section{Methods}

\subsection{Earthquake Hypocenter and Uncertainty Determination}

[15] Hypocenters have been computed using a modified version of the minimum 1-D velocity model determined by O'Keefe [2008] (Table 2), in which we have removed the uppermost layer, that represented a mean surface velocity layer for stations on sediments and bedrock in the analysis of O'Keefe [2008]. This layer is unnecessary in our case, since the majority of the SAMBA stations are situated on hard rock. Shear wave velocities are determined using a $\mathrm{V}_{\mathrm{P}} / \mathrm{V}_{\mathrm{S}}$ ratio of 1.68 as obtained by $O^{\prime} K e e f e$ [2008]. This simple 1-D velocity model was favored over existing 3 -D models of Eberhart-Phillips and Bannister [2002] and Brikké [2010] due to its simplicity and similarity to $1-D$ velocity structures determined previously in active seismic reflection/ refraction studies [Smith et al., 1995; Kleffman et al., 1998; Scherwath et al., 2002] and from earthquake inversion [Eberhart-Phillips, 1995; Leitner et al., 2001]. The 3-D velocity models lack sufficient resolution at shallow depths for our purposes, having been derived on regional scales with $8 \mathrm{~km}$ node spacing in the uppermost crust. Moreover, the complex near-surface-structure of these models make them difficult to apply in this study.

[16] Earthquakes are initially located using SEISAN and are then relocated using the non-linear location programme NonLinLoc 5.0 [Lomax et al., 2000], to better constrain the posterior uncertainties in the hypocenter parameters (for details see Appendix B). The uncertainty of the earthquake location is represented by sampling of the probability 
Table 3. Weight Assigned to the Observed Phase Arrival Time According to Its Deviation From the Mean Phase Arrival Time at Each Station

\begin{tabular}{ccc}
\hline Weightcode & Contribution (\%) & $\begin{array}{c}\text { Absolute Deviation } \\
\text { From the Mean (s) }\end{array}$ \\
\hline 0 & 100 & $<0.1$ \\
1 & 75 & $\geq 0.1$ \\
2 & 50 & $\geq 0.2$ \\
3 & 25 & $\geq 0.4$ \\
4 & 0 & $\geq 0.8$ \\
\hline
\end{tabular}

density function. Several parameters have to be predefined in NonLinLoc, which directly influence the uncertainty volume. These parameters are (1) $\sigma^{\text {model }}$, the typical model error of the travel-time residual; (2) $\mathrm{L}_{\text {corr }}$, which is an estimate of the characteristic length scale of the velocity anomaly between two stations; (3) $\Delta \sigma^{\text {model }} / \sigma^{\text {model }}$, which gives an estimate of the model error on the total uncertainty in proportion to the travel-time; and (4) $\sigma_{\min }^{\text {model }}$ and $\sigma_{\max }^{\text {model }}$, which set lower and upper limits on the travel-time error due to unmodeled velocity structure.

[17] The first two parameters, $\sigma^{\text {model }}$ and $\mathrm{L}_{\text {corr }}$, are needed for the calculation of the model-error covariance matrix [Tarantola and Valette, 1982], which describes whether a correlation in the model errors exists between two stations. We tested values of $1,4,8$ and $80 \mathrm{~km}$ for $\mathrm{L}_{\text {corr }}$, with the latter two representing the average and the maximum station distance. The differences in the resulting uncertainty volumes were minimal and we set $\mathrm{L}_{\text {corr }}$ to $8 \mathrm{~km}$, an anomaly length which we expect to be able to resolve with the station spacing.

[18] In order to estimate the Gaussian uncertainty of the arrival-time readings and the calculated travel-times for the earthquakes recorded in this study, we have performed a comprehensive analysis of the travel-time residuals for the SAMBA data (see Appendix C). This analysis showed that the typical model error $\sigma^{\text {model }}$ of the travel-time residual is small for the SAMBA station network in comparison to the reading error (see Table $\mathrm{C} 1$ ). We obtain estimates of the reading error by two independent means. First, we determine the standard deviation of the travel-time residuals for all stations, and second, we analyze lag-times obtained from cross-correlation of similar events in a swarm: Both indicate that the reading error dominates the observational error. For this reason, we use the (pre-weighting) mean of the traveltime residuals over all stations, $0.075 \mathrm{~s}$, as the typical model error $\sigma^{\text {model }}$. This parameter has the largest effect on the hypocenter uncertainty: for example, doubling this value increases the mean maximum error of the uncertainty volume (depth uncertainty) by 1.5 and quadrupling it causes a 2.5-fold increase. A similar dependency is observed for the mean intermediate error, which is considered here as representative for the horizontal uncertainty. We note for comparison that Wittlinger et al. [1993], who investigated the microseismicity of a $20 \mathrm{~km}^{2}$ gas reservoir with a nine station network (minimum spacing of $2 \mathrm{~km}$ ), chose the dominant P-wavelength of $0.5 \mathrm{~km}$ as the correlation length and a model error of $0.071 \mathrm{~s}$, corresponding to a maximum velocity error $0.1 \mathrm{~km} / \mathrm{s}$.

[19] Error limits for the model error are here set to 0 and $0.2 \mathrm{~s}$. The maximum value was obtained for station POCR which exhibits (pre-weighting) mean model errors of 0.17 and $0.16 \mathrm{~s}$ for P and S-phases. This station is the only station located in a sediment-filled valley, so the assumed velocity model is not fully suitable for this setting. Our estimate for the model error as a fraction of the whole travel-time is obtained for a sample set of 46 earthquakes, distributed across the study area and recorded at all stations. We calculate values of $0-9 \%$ with mean values of $3.3 \%$ for the $P$ and $1.6 \%$ for the S-phase travel-times. We assume hereafter that $5 \%$ of the travel-time is a reasonable representation of the velocity model uncertainty.

\subsection{Systematic Weighting of the Phase Arrival-Times}

[20] Due to concerns that the weights assigned to the phase arrival-times do not accurately represent the uncertainty of the phase pick, we derived a more consistent and objective posterior weighting scheme. The travel-time residuals of all phase-arrivals for earthquakes recorded in this study showed that impulsive and emergent phase arrivaltimes have comparable variances (see Table $\mathrm{C} 1$ ). The stations, however, do not have common variances. This means, we cannot use the weighting proposed by Jeffreys [1973], which depends on the width of the initial residual distribution and is only applicable if different stations have common variances. However, Jeffreys' weighting function can be used to exclude those travel-time residuals in the tails of the distribution (residuals that would contribute less than $5 \%$ in the location process). All remaining travel-time residuals are weighted according to their deviation from the mean traveltime residual obtained for a particular station. This combination of weighting and outlier rejection allows us to identify mispicked phases and to assign a reliable weight to each phase. Table 3 summarizes how the deviation of the traveltime residual from the mean at each station is translated into a weight used in the location process.

\subsection{Magnitudes}

[21] Earthquake magnitudes are determined from waveform amplitudes corrected for geometric spreading and attenuation according to

$$
\mathrm{M}_{\mathrm{L}}=\log _{10} \mathrm{~A}(\Delta)+\alpha \log _{10} \Delta+0.4343 \gamma \Delta+\mathrm{S} .
$$

Here $\mathrm{A}$ is the measured amplitude, $\alpha$ is the geometrical spreading factor, $\gamma$ is the anelastic attenuation parameter, $\Delta$ is the hypocentral distance and $\mathrm{S}$ is a site-specific station term. Amplitude-readings $\mathrm{A}(\Delta)$ are obtained from half the peak-to-peak displacement on one of the horizontal components of a pseudo-Wood-Anderson seismograph, simulated in SEISAN (version 8.2.1, October 2008, and 8.3, May 2010) [Havskov and Ottemöller, 2000]. It is assumed that the gain of the Wood-Anderson instrument is $2080 \pm 60$, as reported by Uhrhammer and Collins [1990].

[22] To determine magnitudes for the SAMBA data, we solve the general inverse problem

$$
\mathbf{Y}=\mathbf{X} \mathbf{m}+\mathbf{e}
$$

by using LU-matrix factorization. The parameters involved in the equation are as follows:

[23] 1. $\mathbf{Y}$ is a two-part vector containing the amplitude readings and the geometrical spreading term $\mathrm{A}_{\mathrm{j}}+\alpha \log _{10} \Delta_{\mathrm{j}}$ of the $\mathrm{j}$-th event, and the magnitudes $\mathrm{M}_{\mathrm{j}}^{\mathrm{c}}$ from the New 
Zealand earthquake catalogue as reported by GeoNet, which are used for calibration of the SAMBA magnitudes $\mathbf{M}_{j}$.

[24] 2. $\mathbf{X}$ is a matrix representing which component of each station has an amplitude reading and which events have calibration magnitudes $\mathbf{M}_{\mathrm{j}}^{\mathrm{c}}$. X also contains the hypocentral distance $\Delta_{\mathrm{jk}}$, where $\mathrm{j}$ marks the event and $\mathrm{k}$ the station.

[25] 3. $\mathbf{m}$ are the parameters of interest, namely the SAMBA magnitudes $\mathrm{M}_{\mathrm{j}}$, the attenuation term $0.4343 \gamma$ and the station correction terms $\mathrm{S}_{\mathrm{k}}$.

[26] 4. $\mathbf{e}$ is a vector of residuals for the SAMBA magnitudes $\Delta \mathrm{M}_{\mathrm{j}}$ and the GeoNet magnitudes $\Delta \mathrm{M}_{\mathrm{j}}^{\mathrm{c}}$ used for calibration.

[27] We have tested the dependency of the data on geometric spreading by separately inverting for the geometrical spreading coefficient $\alpha$ only. We obtain $\alpha=1.6$. For geometric spreading due to expansion of the direct earthquake waves in space, we would expect $\alpha=1$. For the focal depths $<20 \mathrm{~km}$ and hypocentral distances of 0-180 km (with only a few measurements for $\Delta>100 \mathrm{~km}$ ) observed in this study, the amplitude readings were predominantly taken from the direct S-wave arrival. We therefore assume $\alpha=1$ and attribute the remaining amplitude decay to the effects of scattering and anelastic attenuation on the magnitude. Considering the hypocentral range and the dominant frequency of the wave, we find that the influence of attenuation can be up to half that of the geometrical spreading.

[28] The anelastic attenuation parameter $\gamma$ is known to be frequency dependent $\gamma=\gamma(\mathrm{f})$, as seen from the relationship between $\gamma$ and the quality factor $\mathrm{Q}$ :

$$
\gamma(\mathrm{f})=\frac{\pi \mathrm{f}}{\mathrm{Q}(\mathrm{f}) \mathrm{v}},
$$

where $\mathrm{v}$ is the S-wave velocity, $\mathrm{Q}(\mathrm{f})=\mathrm{Q}_{0} \mathrm{f}^{\nu}$ is a function of $\mathrm{f}$ containing the quality factor $\mathrm{Q}_{0}$ at a reference frequency $\mathrm{f}=1 \mathrm{~Hz}$ and $\nu$ is the frequency exponent [e.g., Kim, 1998]. Eberhart-Phillips et al. [2008] studied 3-D attenuation in central South Island by analyzing spectra of 5695 verticalcomponent velocity seismograms of earthquakes larger than $\mathrm{M}_{\mathrm{L}}$ 2.5. For the observed frequency range of the local earthquakes of 2-40 Hz, Eberhart-Phillips et al. [2008] were able to fit the spectra equally well with both frequencyindependent and frequency-dependent Q. Abercrombie [1998, and references therein] found a clear change in frequency dependence of $\mathrm{Q}(\mathrm{f})$ at $10 \mathrm{~Hz}$. Although EberhartPhillips et al. [2008] determined $\mathrm{Q}_{\mathrm{P}}$, we assume here that $\mathrm{Q}_{\mathrm{S}}$ can be treated similarly as frequency-independent, so we set $\nu=0$ and $\mathrm{Q}=\mathrm{Q}_{0}$. We invert for $\gamma=\gamma_{0} \mathrm{f}$ according to equation (3).

\subsection{Focal Mechanisms}

[29] We determine focal mechanism solutions from Pwave first motion polarities for earthquakes recorded by the SAMBA array using the Bayesian approach of Walsh et al. [2009]. This method treats observational uncertainties probabilistically in order to account for polarity errors arising from low signal-to-noise ratios and incorrectly wired seismometers, hypocenter location uncertainties, and imprecise knowledge of the seismic velocity structure. The prior probability of a falsely wired seismometer is here set to $20 \%$, as suggested by Hardebeck and Shearer [2002] for emergent polarity picks of similar event clusters in the
Northridge area, California. We do not discriminate between impulsive and emergent polarity picks, although Hardebeck and Shearer [2002] found that only 10\% of the impulsive polarities were inconsistent. Uncertainty in the hypocenter location results in a variety of possible raypaths from the hypocenter to the receivers and, therefore, in a range of possible take-off angles and azimuths. This causes a cloud of corresponding positions on the focal sphere. The density and the distribution of these points depend predominantly on the uncertainty in depth, since this is usually larger than the horizontal uncertainty. As an example, a change in depth of $1 \mathrm{~km}$ for earthquakes shallower than $7 \mathrm{~km}$ can cause a change in the take-off angle of up to $15^{\circ}$ for upgoing rays (Hardebeck and Shearer [2002], assuming a 1D-velocity model with a gradient of $\mathrm{dV} / \mathrm{dz}=0.25 \mathrm{~s}^{-1}$ and $\mathrm{V}_{0}=4.7 \mathrm{~km} / \mathrm{s}^{-1}$ ). Hardebeck and Shearer [2002] and Walsh et al. [2009] investigated the effect of the velocity model on the polarity distribution on the focal sphere. Hardebeck and Shearer [2002] found that the influence of the velocity model on the focal mechanism is larger than uncertainty in hypocenter location. Since take-off angles at shallow depth are most sensitive to the velocity model, the focal mechanisms of deeper earthquakes show smaller changes resulting from changes in the velocity model [McKenzie, 1969; Hardebeck and Shearer, 2002].

[30] To characterize the uncertainty of the focal mechanism solution, we use the estimate of the standard deviation $\sigma_{\Theta}$ of the focal mechanism parameters by Arnold and Townend [2007]

$$
\sigma_{\Theta}=\exp (3.9155-0.5659 \log \kappa)
$$

where $\kappa$ is the scalar concentration parameter resulting from the concentration matrix of the Matrix-Fisher distribution [see, e.g., Walsh et al., 2009]. This approach assumes equal errors in strike, dip and rake.

\subsection{Stress Inversion}

[31] Assuming that individual focal mechanisms represent a uniform state of stress and are driven by the same stress tensor, regional stress estimates can be derived by inverting a set of independent focal mechanism observations. We apply the Bayesian approach developed by Arnold and Townend [2007] which accounts for observational errors and fault plane ambiguities in the focal mechanism solutions to estimate tectonic stress parameters.

\section{Results}

\subsection{Earthquake Locations and Their Uncertainties}

[32] A total of 1791 events were recorded between November 2008 and December 2009 in the study area (see Data Set S1 of the auxiliary material). ${ }^{1}$ All events recorded by more than five SAMBA stations $(87.3 \%)$ are shown with their uncertainties (Figure 3a), in comparison with the long-term seismicity (Figure 3b), and with magnitudes (Figure 3c). In order to show the depth variation of the hypocenter distribution along the strike of the Alpine Fault, the events are projected onto depth profiles in Figure 4.

\footnotetext{
${ }^{1}$ Auxiliary materials are available at $\mathrm{ftp}: / / \mathrm{ftp}$. agu.org/apend/jb/ 2011 jb008460.
} 
a)

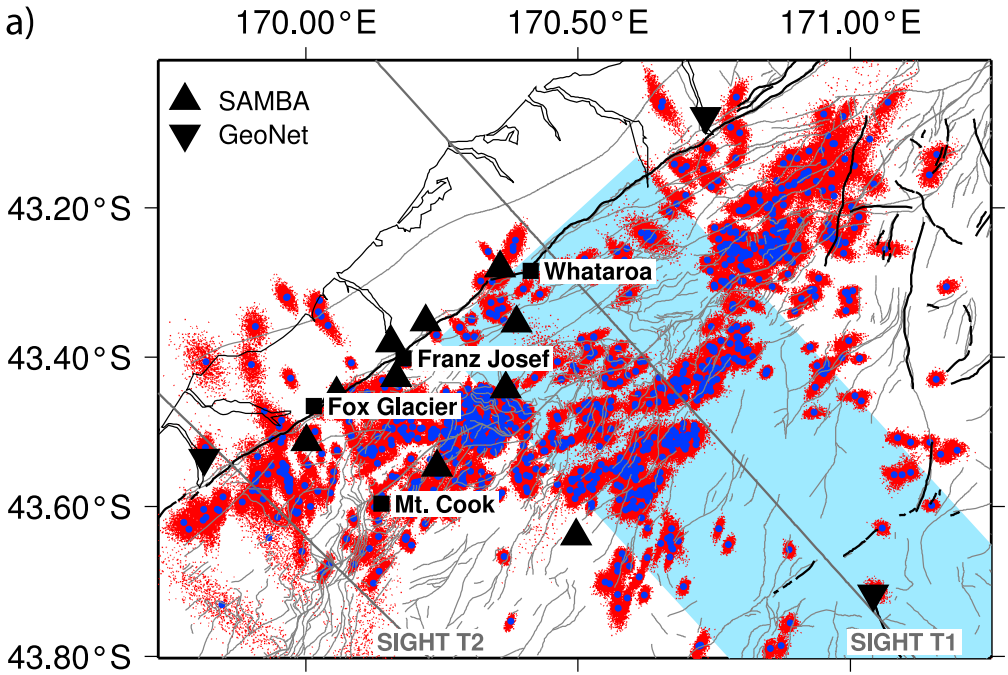

b)

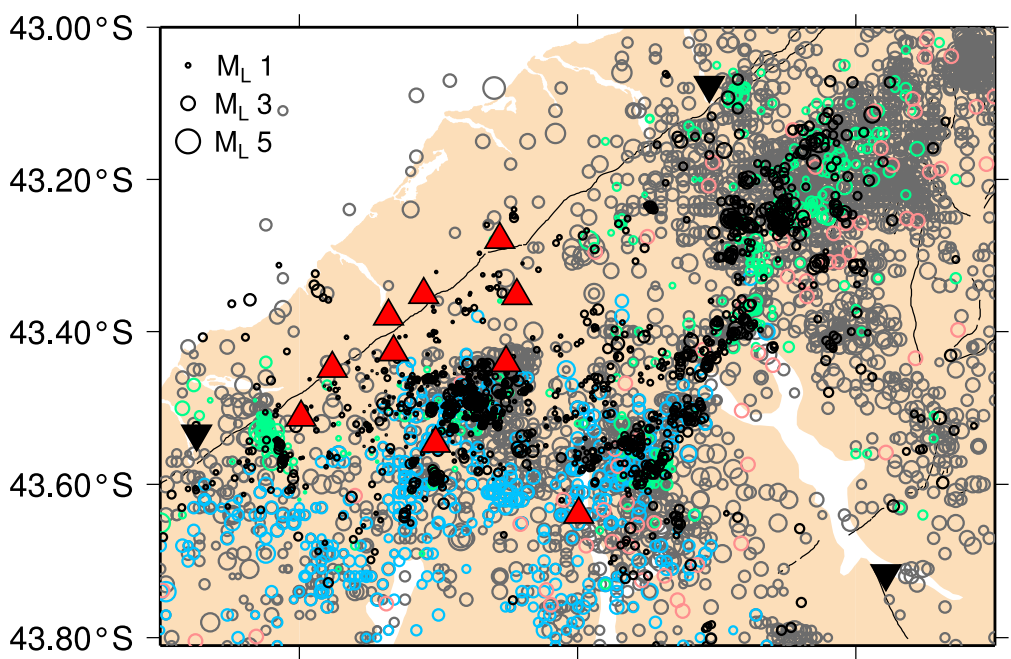

c)

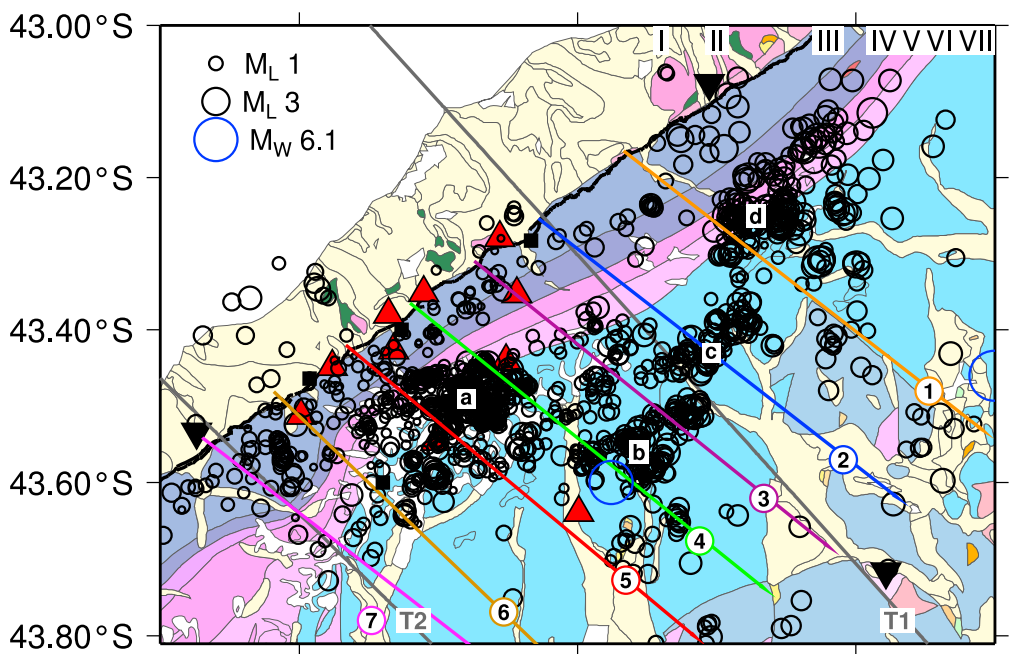

Figure 3 
[33] The error volume projected onto the horizontal plane is approximately circular for most of the earthquakes within the station network (Figure 3a), reflecting a uniform distribution of the recording stations around the events (azimuthal gaps for events in the inner triangle range between $57^{\circ}$ and $192^{\circ}$; see also Figure 6 for all events).

[34] The uncertainty in depths is controlled by the station distribution and varies throughout the network. Depth uncertainty increases markedly when there is no station within a distance of 1.5 focal depths of the earthquake. For this reason, vertical uncertainties increase toward the boundaries of the SAMBA network (as seen in depth transects 1, 2 and 7 of Figure 4). Since the resolution of the hypocenter uncertainty varies throughout the study area, mean depth and mean uncertainties are displayed by grey bars in the background of the profiles in Figure 4. Hypocenter depths are best constrained in the vicinity of the Alpine Fault where the station distribution is the densest (as can be seen by the increase in the error bars with distance from the Alpine Fault).

[35] The distribution of the minimum hypocentral distances of all events to the nearest stations, as an indicator of the range of well-constrained depths, is bimodal with modes at 7 and $20 \mathrm{~km}$. Its mean is $14 \mathrm{~km} \pm 9.5(1 \sigma) \mathrm{km}$. Consequently, deeper events are better constrained in the whole study area. To further assess the absolute location error within the station array, we use the mean inter-event distance of earthquakes in three swarms that occurred between stations WHYM and LABE between November 2008 and December 2009. Assuming that all events in the swarm occurred at the same location in space, we use twice the maximum distance of the catalogue events from the cluster center as a measure of the absolute location uncertainty [cf. Clarke, 2008]. Values range between 0.43 and $1.35 \mathrm{~km}$ horizontally and 1.76 to $2.96 \mathrm{~km}$ in depth.

[36] A comparison of the long-term background seismicity recorded by GeoNet during the last 20 years with the shortterm seismicity recorded by SAMBA over 14 months (Figure 3b) demonstrates distinct spatial patterns of quiescence and persistent activity in the epicentral distribution. Earthquakes are spatially clustered and occur in patches along and to the east of the Main Divide Fault Zone (MDFZ) (Figure 1), a major backthrust off the Alpine Fault [Cox and Findlay, 1995]. The earthquakes are not confined to mapped surface fault traces (as shown in Figure 3a) but are distributed throughout an approximately $25 \mathrm{~km}$-wide region. However, there is some indication of reduced seismic activity in a $15 \mathrm{~km}$-wide zone adjacent to the Alpine Fault that coincides with the average width of the Alpine schist [Little et al., 2005; Cox and Sutherland, 2007] (textural zones III and IV in Figure 3c). This may reflect different amounts and characteristics of fractures in the schist relative to the greywacke further southeast.

[37] Four distinct clusters stand out in the seismicity distribution (letters in Figure 3c). Cluster a occurs in the middle of the SAMBA array, has well-constrained depths $<7 \mathrm{~km}$, and comprises small events of $\mathrm{M}_{\mathrm{L}}<2.5$. Cluster $\mathrm{b}$ may represent continuing aftershocks of the $\mathrm{M}_{\mathrm{W}} 6.1$ Godley River earthquake. Cluster $\mathrm{c}$ is confined to a northeasttrending high-seismicity zone which occurs within $30 \mathrm{~km}$ of the Alpine Fault. It borders a distinct aseismic gap that extends north-westward to the surface trace of the Alpine Fault between the Wanganui and Whataroa rivers (Figure 2). The fourth cluster, $d$, occurs at the northeastern boundary of the study area, has poorly constrained depths and significantly larger magnitudes $\left(\mathrm{M}_{\mathrm{L}}<3.5\right)$. The depth distribution of clusters $\mathrm{b}, \mathrm{c}$ and $\mathrm{d}$ can at best be partially resolved.

[38] Figure 4 shows the earthquake hypocenters projected onto profiles perpendicular to the Alpine Fault. Three of these transects coincide with geological cross sections by Little et al. [2005]. The north-easternmost profile 1 (orange hypocenters) shows distinct clusters of events approximately 8 and $16-25 \mathrm{~km}$ southeast of the fault. The latter cluster coincides with the MDFZ (as indicated by a diamond in all profiles). In the Whataroa river valley (transect 2 , blue hypocenters), few earthquakes occur close to the Alpine Fault. Events cluster at about $30 \mathrm{~km}$ distance from the Alpine Fault (cluster c) over a wide depth range. These depths are quite uncertain (mean depth uncertainty $5 \pm 1.6$ $(1 \sigma) \mathrm{km})$ as there is no station in the vicinity, but the hypocenters align with a steeply dipping fault mapped at the surface [Little et al., 2005, Figure 3a]. To the south, profile number 3 (purple hypocenters) reveals a distinct earthquake cluster within $5 \mathrm{~km}$ of the surface trace of the Alpine Fault and a number of events between 15 and $40 \mathrm{~km}$, increasing in depth with distance from the fault. Transect 4 (green hypocenters) shows several events $2-8 \mathrm{~km}$ southeast of the surface trace of the Alpine Fault at depths consistent with the estimated position of the fault. Abundant earthquakes with shallow hypocentral depths occur at $15 \mathrm{~km}$ distance to the fault trace (cluster a). At greater distances, the earthquake depths increase monotonically. Profiles 5 (red hypocenters, average uncertainty $\pm 2.6 \mathrm{~km}$ ) and 6 (brown hypocenters, average uncertainty $\pm 3 \mathrm{~km}$ ) indicate a bulge in

\footnotetext{
Figure 3. (a) Epicentral locations of events recorded by more than 5 stations between November 2008 and December 2009. Earthquake hypocenters were determined using the non-linear location programme NonLinLoc of Lomax et al. [2000]. The probability density function (red) of each earthquake represents the uncertainty of the hypocenter location, the blue dot marks the maximum likelihood hypocenter location. The light blue area shows which earthquake hypocenters are projected onto SIGHT transect T1 as shown in Figure 5. (b) Seismicity recorded in the central Southern Alps since 1984 by GeoNet (grey), Reyners [1988] (blue), Leitner et al. [2001] (red), O'Keefe [2008] (green) and in this study (black). (c) Epicenters as shown in Figure 3a with the symbol size representing the magnitude. Colored lines and numbers indicate the depth profile onto which events within $\pm 5 \mathrm{~km}$ are projected (Figure 4). Letters are used to mark seismicity clusters described in the text. In the background, a simplified geological map based on the geological data from the 1:1000000 Geological Map of New Zealand (Officers of the New Zealand Geological Survey 1972 with limited updates by P. J. Forsyth and N. Mortimer (2004)) is shown. Textural zones are I Quaternary deposits, II Paleozoic and Mesozoic Western Province basement (gneis, granite, granodiorite), III Rakaia Terrane mylonite, curly schist and schist, IV Rakaia Terrane schist, V + VI Rakaia Terrane semi-schist, VII Rakaia Terrane greywacke sandstone and mudstone according to Cox and Sutherland [2007].
} 

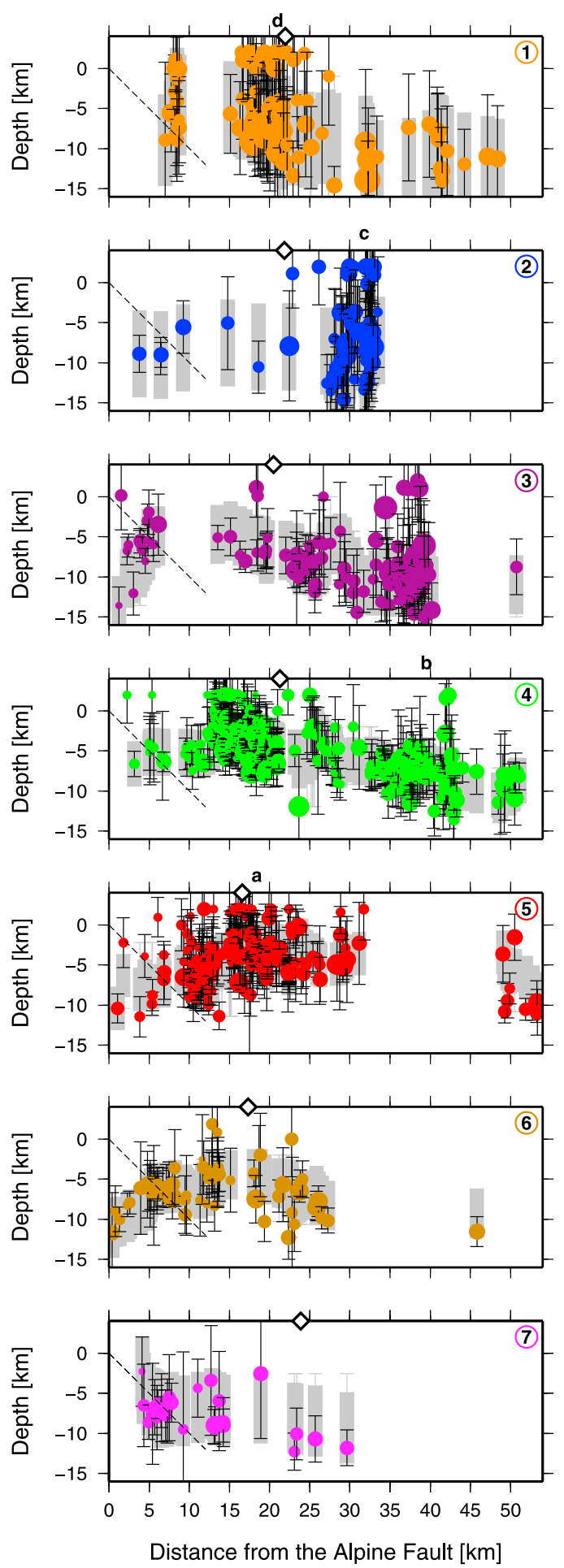

Figure 4. Hypocentral depth and depth uncertainty of earthquakes projected onto the corresponding profiles (number and color) shown in Figure 3c, with the symbol size representing the magnitude of the event. Grey bars indicate mean depth and mean uncertainties (over seven points) for the events shown in the profile. Letters a-d indicate the position of clusters (Figure 3c) along the profile. Diamonds indicate the surface position of the Main Divide Fault Zone. The dashed line indicates the Alpine Fault for an assumed $\operatorname{dip}$ of $45^{\circ}$. the seismicity with a radius of curvature of $\sim 10 \mathrm{~km}$ despite the depth uncertainty. Events near the Alpine Fault and $20 \mathrm{~km}$ southeast of the surface trace occur at larger depths than those events centered around the MDFZ (depths of $6 \mathrm{~km})$. In this region, the distance between MDFZ and the Alpine Fault is narrowest (15 km versus $30 \mathrm{~km}$ elsewhere) [Cox and Findlay, 1995]. Transects 5 and 6 exhibit few events $45-50 \mathrm{~km}$ from the Alpine Fault trace, but in general earthquakes occur within a narrow zone close to the Alpine Fault. Transect number 7, which straddles the southern boundary of the SAMBA network, reveals a cluster of events $4-8 \mathrm{~km}$ southeast of the surface trace at depths possibly associated with the Alpine Fault. The remaining events exhibit increasing depths with distance from the fault but the uncertainty in depth is quite large $(4 \pm 2.9 \mathrm{~km})$.

[39] Figure 5 shows the projection of earthquakes within $20 \mathrm{~km}$ on either side of SIGHT transect 1 (light blue area in Figure 3a) and six large earthquakes since 1946 from elsewhere (Figure 1) onto the resistivity profile by Wannamaker et al. [2002]. The depth-distribution of those earthquake hypocenters reveals that the seismogenic zone varies from northwest to southeast across the Southern Alps but nowhere it exceeds $17 \mathrm{~km}$. The seismicity correlates with the highresistivity regions and is clustered where the resistivity gradient is high. Wannamaker et al. [2002] interpreted the low-resistivity regions as zones of interconnected fluids, which are trapped within the mylonized, ductile shear zone. The six largest events (as shown by white circles in Figure 5) occur at greater depths on average than the lower-magnitude seismicity, probably at the base of the seismogenic zone [Sibson, 1984] in this region.

[40] A histogram of the depths of all events is shown in Figure 6 . This distribution has a mode at $6 \mathrm{~km}$ depth due to the large number of shallow events in the center of the SAMBA array (profiles 4 and 5 in Figure 4). The second maximum at the surface results from inconsistent phase arrival times or hypocenter locations outside the station network with poor depth resolution.

\subsection{Magnitudes}

[41] We obtain a frequency-dependent attenuation factor $\gamma(\mathrm{f})=\gamma_{0}$ f with $\gamma_{0}=1.89 \pm 0.02 \times 10^{-3} \mathrm{~s} / \mathrm{km}$, resulting in $\gamma=1.89 \times 10^{-2} \mathrm{~km}^{-1}$ at $10 \mathrm{~Hz}$ (representative at distances $<70 \mathrm{~km})$ and $\gamma=0.95 \times 10^{-2} \mathrm{~km}^{-1}$ at $5 \mathrm{~Hz}(\geq 70 \mathrm{~km})$ (Figure 7). Our result is in agreement with estimates by Robinson [1987] $\left(\gamma=0.67 \times 10^{-2} \mathrm{~km}^{-1}\right)$ and O'Keefe [2008] $\left(\gamma=1.69 \times 10^{-2} \mathrm{~km}^{-1}\right)$, depending on the hypocentral distance of the earthquake to the station. The corresponding frequency-independent quality factor $\mathrm{Q}$ for direct $\mathrm{S}$-waves is $\mathrm{Q}_{\mathrm{S}}=531 \pm 53$, a reasonable value in comparison with the $\mathrm{Q}_{\mathrm{P}}$ of $250-800$ determined by Eberhart-Phillips et al. [2008] for the central Southern Alps. Eberhart-Phillips et al. [2008] found that a sharp boundary exists between weakly attenuating schist and highly attenuating regions of altered schist for the shallow $Q_{P}$-structure in the central Southern Alps (depths $<10 \mathrm{~km}$ ). $Q_{P}$ values of $\sim 800$ were attributed to the Haast schist, which is inferred to be depleted of fluids and highly compacted due to dehydration during metamorphism and intense deformation, respectively. In contrast, Torlesse greywacke has moderate to low $Q_{P}$ of $\sim 450$. Low crustal $Q$ values typically result from fluid saturation and high 


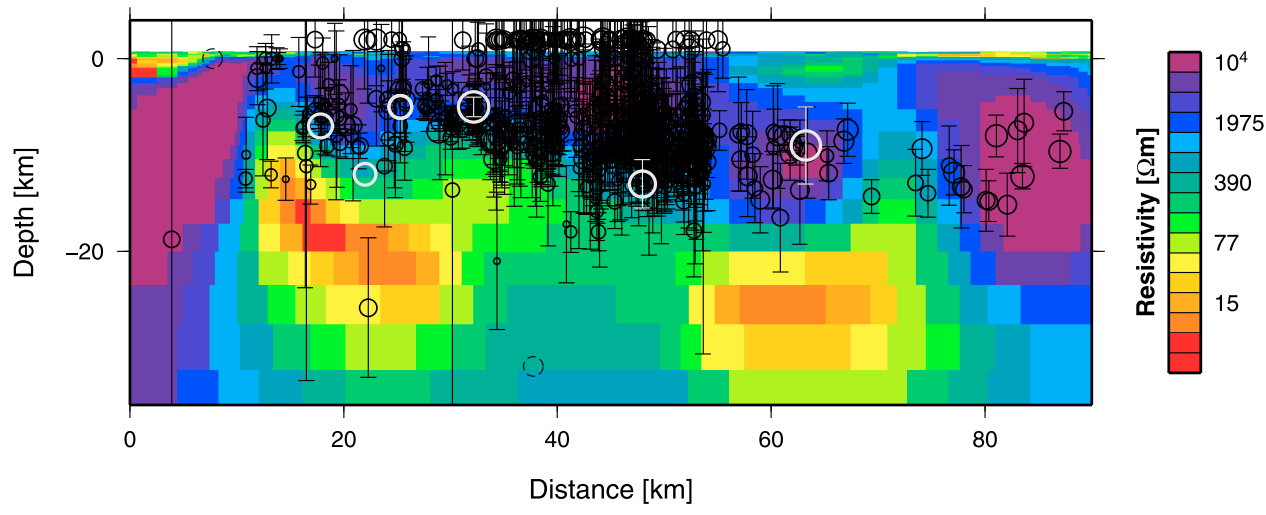

Figure 5. Hypocenter locations and depth uncertainty of local earthquakes (within $20 \mathrm{~km}$ of the transect, black) and large earthquakes (in the Southern Alps region, white, see Figure 1 and Table 1 for details) projected onto SIGHT transect T1, for which a resistivity model has been derived by Wannamaker et al. [2002]. Note that the average topography is $1.5 \mathrm{~km}$ in this area and that for distances $\geq 60 \mathrm{~km}$, earthquakes fall outside the recording range of the SAMBA network. Depth uncertainties are calculated from the maximum length of the uncertainty volume determined using NonLinLoc. Reprinted by permission from Macmillan Publishers Ltd: Nature (Wannamaker et al. [2009]), (C2009.

temperature. Eberhart-Phillips et al. [2008] state that the $\mathrm{Q}_{\mathrm{P}}$ depth profile in the central Southern Alps closely matches the resistivity model of Wannamaker et al. [2002]. A correlation of the seismicity distribution with low $\mathrm{Q}_{\mathrm{P}}$ was observed by Eberhart-Phillips et al. [2008] and interpreted to represent highly fractured crust and increased fluid volumes in conjunction with fractures. The $\mathrm{Q}_{\mathrm{P}}$ values for the Haast Schist and the damage zone in the central Southern Alps, assuming that $\mathrm{Q}_{\mathrm{P}} \sim \mathrm{Q}_{\mathrm{S}}$, can be used to constrain the attenuation parameter $\gamma$ (according to equation 3 ), yielding $\gamma\left(\mathrm{Q}_{\mathrm{P}}=800\right)=0.5 \times 10^{-2} \mathrm{~km}^{-1}$ and $\gamma\left(\mathrm{Q}_{\mathrm{P}}=200\right)=$ $3.45 \times 10^{-2} \mathrm{~km}^{-1}$ at a frequency of $5 \mathrm{~Hz}$ and an S-wave velocity of $3.2 \mathrm{~km} / \mathrm{s}$. These values provide upper and lower limits for the attenuation parameter. The attenuation coefficients we obtain for frequencies between 3 and $17 \mathrm{~Hz}$ lie within these bounds.

[42] We find that it is necessary to fit the amplitude readings with a frequency-dependent attenuation coefficient. Otherwise, we obtain a high constant attenuation coefficient of $\gamma \sim 2 \times 10^{-2} \mathrm{~km}^{-1}$ and uniformly positive magnitude residuals for hypocentral distances greater than $70 \mathrm{~km}$ (Figure 7). The magnitudes determined using our frequencydependent attenuation coefficient are not significantly different from those obtained by GeoNet $\left(1 / N \sqrt{\sum\left(M_{j}^{c}-M_{j}\right)^{2}}\right.$ $\leq 0.1$ ). However, our preferred attenuation parameter produces consistent results for earthquakes of different sizes and frequency contents.

[43] The magnitudes obtained for earthquakes recorded in the study area span $-0.3 \leq \mathrm{M}_{\mathrm{L}} \leq 4.2$ (Figure 8). Earthquakes of low magnitude $\left(\mathrm{M}_{\mathrm{L}} \leq 2.5\right)$ occur in great numbers in the center of the station network (orange triangle), conversely events with magnitudes $\mathrm{M}_{\mathrm{L}} \geq 3$ are distributed to the northeast of the SAMBA array (Figure 3c).

[44] The magnitudes determined in this study were calibrated using the magnitudes obtained by GeoNet [e.g., Ristau, 2009]. For 147 of the larger earthquakes $\left(1.6 \leq \mathrm{M}_{\mathrm{L}} \leq\right.$ 4.2) magnitude estimates are available (Figure 8). However, magnitude calibration implies that if the reference values are consistently overestimated, so will be the SAMBA magnitudes. Comparisons of $\mathrm{M}_{\mathrm{W}}$ estimates obtained from waveform modeling [Ristau, 2008; Leitner et al., 2001] with $\mathrm{M}_{\mathrm{L}}$ estimates for the central Southern Alps indicate that $\mathrm{M}_{\mathrm{L}}$ values overestimate the actual energy release by at least 0.2 but more likely 0.5 magnitude units. Deichmann [2006] estimated that local magnitude errors due to uncorrected attenuation effects for events of $\mathrm{M}_{\mathrm{W}}<1$ can amount to more than a whole magnitude unit. Due to the frequency-dependent attenuation factor, we consider the effect of uncorrected attenuation to be small. However, the size of the events relative to each other is more reliable than the absolute value, which might be uncertain by approximately half a magnitude unit. Once there are more $\mathrm{M}_{\mathrm{W}}$ estimates from moment tensor inversion available for earthquakes recorded by SAMBA (currently only two events), we will repeat our magnitude inversion using these $\mathrm{M}_{\mathrm{W}}$ for calibration.

\subsection{Focal Mechanisms}

[45] Focal mechanism solutions for earthquakes recorded by the SAMBA network were determined for events with seven or more P-wave polarity picks. Two deep teleseismic events $\left(\mathrm{M}_{\mathrm{W}} 6.6\right.$ of 4 October 2009, 10:58:03.6 UTC at $626 \mathrm{~km}$ depth and $\mathrm{M}_{\mathrm{W}} 6.9$ of 28 August 2009, 01:51:25.9 UTC at $634 \mathrm{~km}$ ) with impulsive P-wave arrivals have been used to check the instrument polarities. This analysis revealed reversed polarities of the Z-component of the Mark Products L-4C3D sensors in comparison with the short-period borehole and the GeoNet broadband sensors. At one site, Reynold's Creek (REYN), all polarity picks have been removed from the data set, since they are inconsistent with those of the other sensors.

[46] Polarities of closely spaced events have been checked in groups for their consistency. Reversed polarity picks were identified for the stations equipped with a borehole and a surface sensor, when the polarity was picked on the Zcomponent of the Mark Products L-4C3D surface sensor 

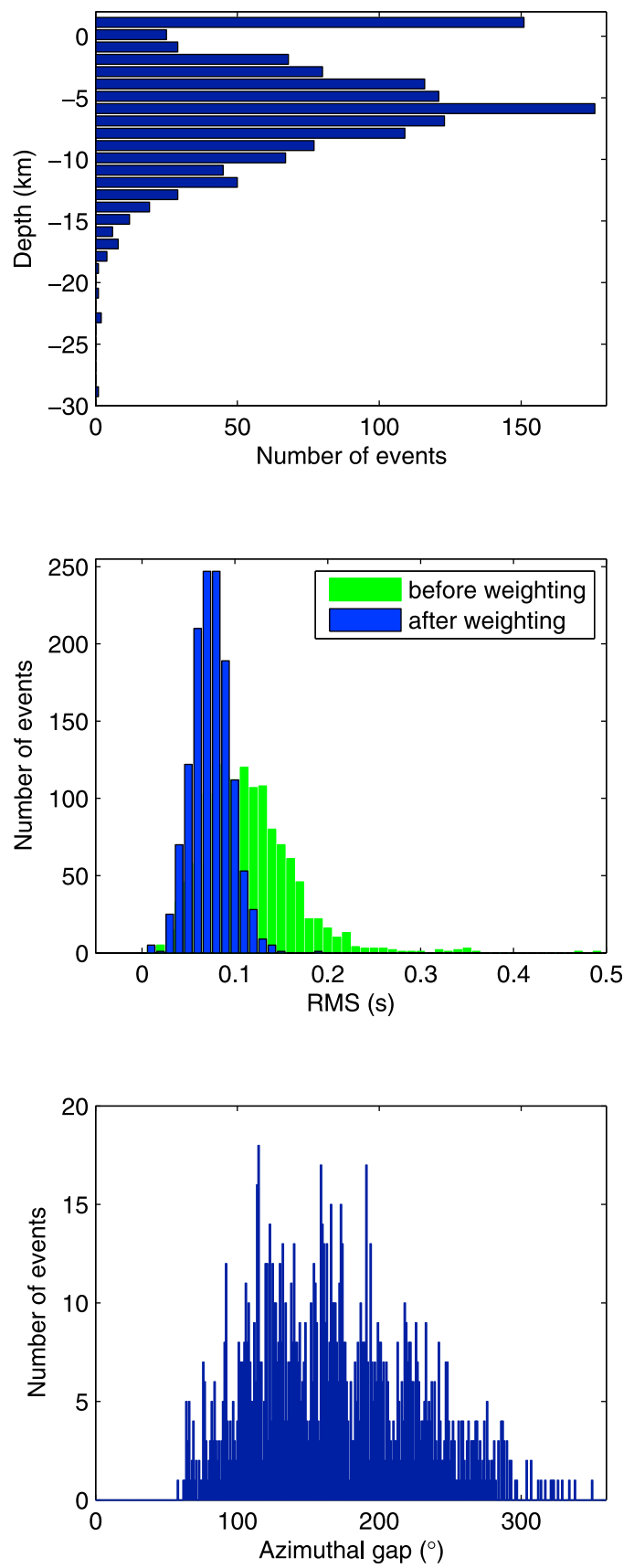

Figure 6. Depth, root-mean squared (RMS) residual and maximum azimuthal gap distribution for all events shown in Figure 3c.

instead of the borehole sensor. These wrong polarity picks are easy to identify by visual inspection. Based on this checking procedure, the assumed probability of inconsistent polarity picks of 0.2 [Hardebeck and Shearer, 2002] is likely to overestimate the number of inconsistent polarities in our data set, since the polarities of the instruments are generally known and wrong polarity picks should be caused by misidentification only.

[47] Due to the network size, the maximum number of available $P$-wave polarities is restricted to 13 . Consequently, good coverage of polarity readings on the focal sphere is uncommon. However, this is an inherent problem of focal mechanism solutions. Those mechanisms obtained for the central Southern Alps region have standard deviations of the focal mechanism parameters of $\sigma_{\Theta}=29 \pm 1.6^{\circ}(1 \sigma)$. Events of this type were considered to be poorly constrained by Walsh et al. [2009] who compared their focal mechanism solutions with those of Reyners and McGinty [1999] for events with polarity picks from up to 36 stations. Their quality estimate was based on the angular difference between the focal mechanism solutions that describes the angular difference between two focal mechanism solutions [e.g., Arnold and Townend, 2007]:

$$
\alpha_{R}=\cos ^{-1}\left(\frac{\operatorname{tr}\left(\mathbf{R}_{1}^{T} \mathbf{R}_{2}\right)-1}{2}\right) .
$$

$\mathbf{R}_{1}$ and $\mathbf{R}_{2}$ are rotation matrices corresponding to the two focal mechanism solutions. In the study of Walsh et al. [2009], the poorly constrained focal mechanism solutions had minimum rotation angles of $21-84^{\circ}$, whereas for the well-constrained solutions the minimum rotation angle was typically $5-26^{\circ}$. Minimum rotation angles of $24-32^{\circ}$ were found by Hardebeck [2006] for three high-quality focal mechanism data sets with events a few hundreds of meters apart. Hardebeck [2006] concluded that these focal mechanism solutions were indistinguishable within error.

[48] We obtained minimum rotation angles of $1-88^{\circ}$ (with a mean of $32 \pm 22^{\circ}$ ), for the focal mechanism solutions of groups of events with similar polarity picks. We conclude that these values fairly describe the uncertainty of the focal mechanism solutions in our data set. One well-defined nodal plane for the focal mechanisms was often observed, indicating that the strike and dip are well constrained but not the rake.

[49] Hardebeck and Shearer [2002] showed that focal mechanisms of earthquakes at shallow depths $(<10 \mathrm{~km})$ are most sensitive to changes in depth, especially for dip-slip events. This is because the take-off angles for upgoing rays are sensitive to changes with the depth of the location. Ray take-off angles to the station are determined from the maximum likelihood hypocenter, which is in the best case centered in the middle of the uncertainty volume. Since we consider the depth uncertainty by calculating a range in takeoff angles, we expect that these mechanisms are not sensitive to small changes in depth. The comparison of our focal mechanism solutions for the central Southern Alps with those of Leitner et al. [2001], Ristau [2008], and Anderson et al. [1993] (Figure 9) shows overall similarity in the mechanisms but differences in the details of the focal mechanism parameters. These differences usually result from the increased uncertainty of one focal mechanism parameter.

[50] Considering the uncertainty in the focal mechanism solutions, it is notable that the majority of our solutions exhibit consistently strike-slip mechanisms. Some thrust mechanisms occur, but fewer than expected for a region in which the fault-normal displacement amounts to approximately one third of the fault-parallel component. This ratio of reverse to strike-slip mechanisms reaches $1: 2$ as expected 

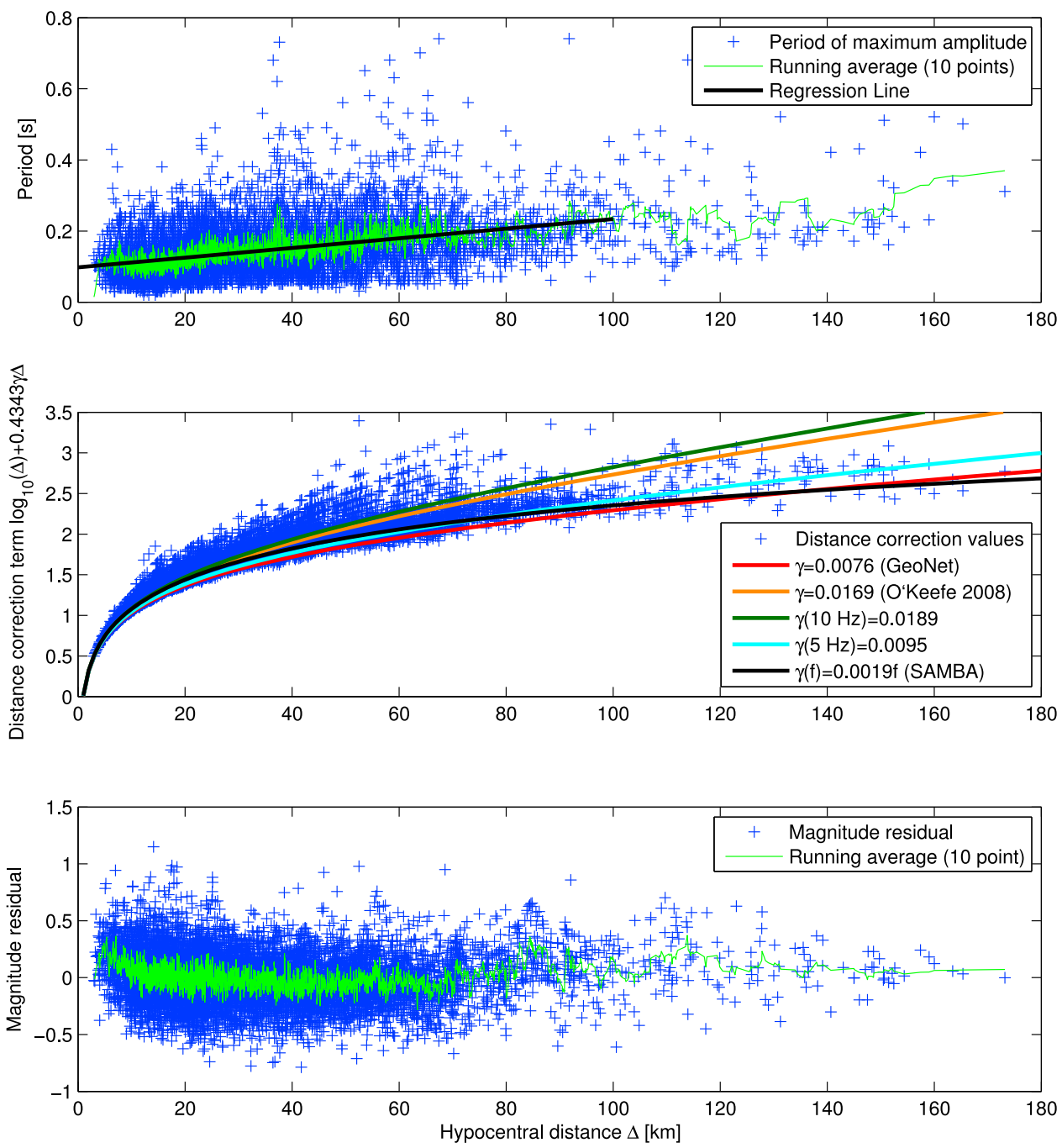

Figure 7. Period of the maximum Wood-Anderson displacement amplitude, attenuation functions and magnitude residuals versus hypocentral distance. The frequency dependence of the maximum amplitude needs to be fitted using a frequency-dependent attenuation parameter $\gamma(\mathrm{f})$ to produce normally distributed magnitude residuals over all hypocentral distances.

for intermediate (black and grey solutions in Figure 9) and large earthquakes (Table 1).

[51] Focal mechanism solutions have been determined for events as small as $\mathrm{M}_{\mathrm{L}}=0.44$. Although the station coverage is best in the vicinity of the Alpine Fault, we have obtain only a few focal mechanism solutions for earthquakes on or close to the fault.

\subsection{Stress Inversion}

[52] The prevailing directions of the principal stresses and the maximum horizontal compression obtained from analyzing clusters of focal mechanisms are shown in Figure 10a. The number of events used for the inversion is indicated by the number next to the stress contour plots. Different clusters exhibit only minor differences in the direction of the maximum horizontal compressive stress $\mathrm{S}_{\mathrm{Hmax}}$ (Table 4) from the average value of $\mathrm{S}_{\mathrm{Hmax}}=115 \pm$ $10^{\circ}$ at the $80 \%$ confidence level. Except for the north-easternmost cluster, where the contours of $\mathrm{S}_{2}$ and $\mathrm{S}_{3}$ overlap, the principal stress directions are well-defined and consistent over the study area. $\mathrm{S}_{2}$ is near-vertical except for the southwesternmost region. Here, a rotation of the $S_{2}-S_{3}$ plane around the $S_{1}$ direction occurs, which increases the reverse component in this area. The stress ratio $\mathrm{R}$, in contrast, varies throughout the study area. Although this parameter is the least constrained in the inversion (Table 4), it reflects the topography throughout the region with low $\mathrm{R}$ values where the topography is highest $\left(\mathrm{S}_{2} \gg \mathrm{S}_{3}\right)$ and $\mathrm{R}$ ranging between $0.5\left(\mathrm{~S}_{2}=0.5\left(\mathrm{~S}_{1}+\mathrm{S}_{3}\right)\right)$ and $1\left(\mathrm{~S}_{2}=\mathrm{S}_{3}\right)$ where the topography decreases. Lund and Townend [2007] showed that the maximum horizontal compressive stress $\mathrm{S}_{\mathrm{Hmax}}$ is less sensitive to variations in $\mathrm{R}$ for strike-slip stress states than for normal or thrust faulting stress states.

[53] Our results are in agreement with previous stress measurements from the South Island. These results are summarized in Table 5 and the most resent results are displayed along with our results in Figure 10b. These consistent angles in the range $107^{\circ}$ to $121^{\circ}$ are as expected for the 

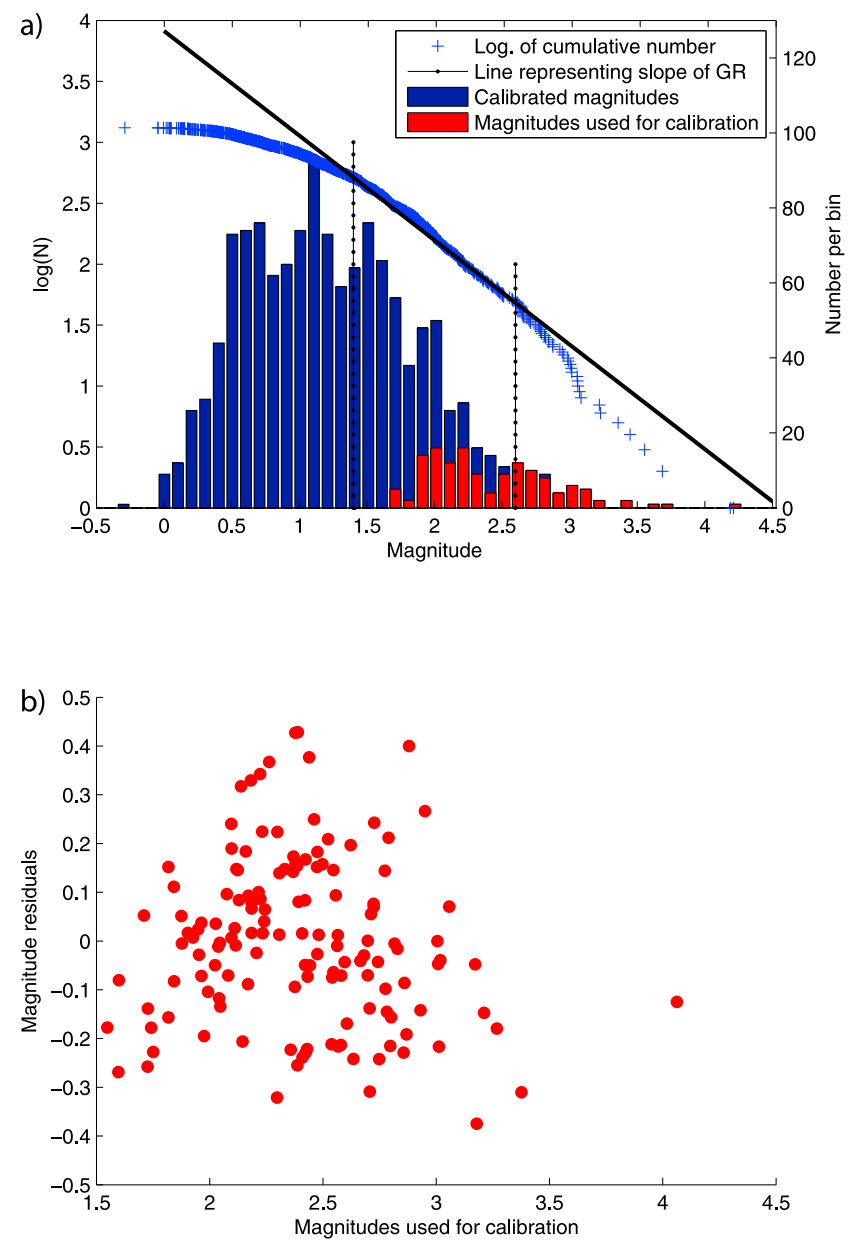

Figure 8. (a) Histograms of the magnitude distribution in the central Southern Alps region recorded by SAMBA (blue) and GeoNet (red) stations. The black line indicates the slope of the Gutenberg-Richter relation (b-value of 0.86 ) of the cumulative number of earthquakes versus magnitude. (b) Residuals of the magnitudes used for calibration in the inversion for all SAMBA magnitudes.

principal axis of contraction $\left(111^{\circ}\right)$ inside a uniformly deforming zone parallel to the Alpine Fault subjected to loading at an azimuth of $077^{\circ}$ by the relative plate motion [Reilly, 1990].

[54] All stress measurements indicate a strike-slip faulting regime prevailing over wide areas of the South Island. A homogeneous, regional stress field has been noted before by Leitner et al. [2001], whose principal stress directions for three broad regions in central South Island were indistinguishable from each other at the $80 \%$ confidence level. Nevertheless, we see some indication for a locally increased reverse component at the southern boundary of our study area. The high topography in the central Southern Alps has little effect on the overall stress field in general, but causes local segmentation of the Alpine Fault's surface trace in thrust and strike-slip segments [Norris and Cooper, 1995]. Based on the stress estimates, we observe that these segments have orientations close to optimal in terms of Andersonian faulting models (inset of Figure 10b). Under the assumption that the horizontal stress is homogeneous, variations in the intermediate stress $S_{2}$ cause a rotation of the strike of a non-vertical strike-slip fault toward $S_{1}$ when there is a deficiency of load, and away from $S_{1}$ as a result of excess topography, according to the equation

$$
\frac{S_{2}-S_{3}}{S_{1}-S_{3}}=1-R=\sin ^{2} \phi
$$

given by Fialko et al. [2005] (where $\phi$ is the angle between the fault trace and the $\mathrm{S}_{1}$-axis). The topography therefore explains the segmentation into strike-slip faults coinciding with mayor river valleys crossing the Alpine Fault and thrust segments at higher angles to the Alpine Fault in regions of high elevation near the fault [see also Norris and Cooper, 1995, Figures 9 and 11].

[55] Our stress inversion results show that the Alpine Fault as a whole is orientated at a high angle $\left(59^{\circ}\right)$ to the direction of maximum horizontal compressive stress (Figure 10b). This implies that the normal stress acting on the fault plane is high. Regarding Andersonian faulting, this angle suggests that the Alpine Fault sustains a low ratio of shear stress to effective normal stress. Balfour et al. [2005] obtained a $60^{\circ}$ angle between the average strike of faults in the Marlborough Fault System and the direction of the maximum horizontal compressive stress. In Southern Marlborough, where the strike of the faults changes to about $070^{\circ}$, this angle lessens to $44^{\circ}$. The San Andreas Fault is orientated at angles ranging between $60^{\circ}$ and $85^{\circ}$ to the maximum horizontal compressive stress [Townend and Zoback, 2004]. In Southern California, this angle between the San Andreas Fault and the maximum horizontal compressive stress direction is almost constant, despite pronounced changes in the strike of the San Andreas fault [Townend and Zoback, 2001, 2004].

[56] Low coefficients of friction have been suggested as the cause for the weakness of the San Andreas Fault [Townend and Zoback, 2004]. This has been confirmed by the low values $(\mu=0.13-0.21)$ measured for the creeping section near Parkfield [Lockner et al., 2011]. Balfour et al. [2005] concluded that the Marlborough faults are also frictionally weak due to either low coefficients of friction (coefficient of friction $\mu=0.35$, pore fluid factor $\lambda=0.4$ ), or increased pore fluid pressure ( $\mu=0.58, \lambda=0.7)$ or due to some combination of the two. This interpretation seems applicable to the Alpine Fault, too. No indication of steady creep on the Alpine Fault has been observed since 1964 on man-made structures crossing the fault [Evison, 1971; Sutherland et al., 2007, and references therein] or by GPS surveying in the Whataroa River [Beavan et al., 1999], but cannot be ruled out in the mountainous region east of the Alpine Fault. Since high pore fluid pressures have been suggested as the cause for the low-velocity zone [Stern et al., 2001] in the vicinity of the Alpine Fault, we favor increased fluid pressures as the cause for the fault's reduced strength.

\section{Discussion and Conclusions}

[57] Hypocenter locations of more than 1700 earthquakes recorded by the SAMBA network have been determined between November 2008 and December 2009 in the central 


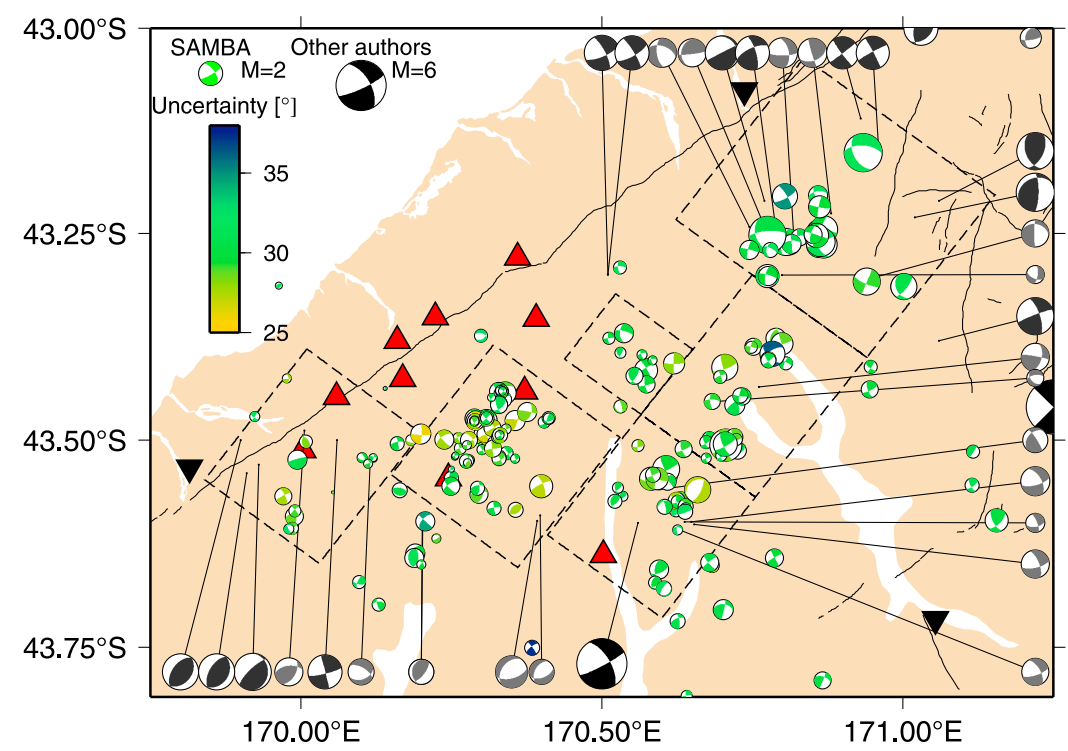

Figure 9. Focal mechanism solutions of 211 events derived in this study (colored according to the uncertainty) and by Ristau [2008], Leitner et al. [2001] and Anderson et al. [1993] (dark grey, light grey and black, respectively). The symbol size represents the magnitude of the event, which is scaled up for the SAMBA data. Detailed information about each focal mechanism solution is listed in Data Set S2 of the auxiliary material.

Southern Alps. The seismicity is diffuse and no particular fault or a small number of faults can be identified from the dense distribution of mapped faults in this region. However, the overall earthquake hypocenter distribution correlates with the boundaries between high and low attenuation zones as shown in the crustal attenuation model of Eberhart-Phillips et al. [2008], despite the rather large node spacing in the central Southern Alps. The Alpine Fault does not appear as a localized zone of deformation from the earthquake distribution. Instead, the inferred deformation is distributed between the Alpine Fault, the Main Divide Fault Zone and other major backthrusts to the east. Many active large faults in New Zealand appear aseismic on intermediate time-scales and are not delineated by the background seismicity [e.g., Anderson and Webb, 1994; Robinson, 2004]. The Alpine Fault, however, is not totally aseismic because it exhibits several clusters of earthquakes $5-8 \mathrm{~km}$ southeast of its surface trace at depths consistent with a $45^{\circ}$-dipping fault. Earthquakes also occur at greater depths closer to the surface trace of the Alpine Fault. Therefore, the existence of a sub-vertical strand of the Alpine Fault, as expected from $\sim 15 \mathrm{Myr}$ of solely strike-slip motion on the fault [e.g., Cande and Stock, 2005], cannot be ruled out. A high concentration of earthquakes on backthrusts at a range of distances from the Alpine Fault is observed, most obviously in the northernmost depth profiles (profiles 2 and 3 and marked by cluster $\mathrm{b}$ and $\mathrm{c}$ ). Otherwise, the hypocenter locations are distributed throughout the whole seismogenic zone $(<17 \mathrm{~km})$, but mean depths generally increase to the southeast across the Southern Alps perpendicular to the Alpine Fault. Earthquakes are anomalously shallow $(<6$ $\mathrm{km})$, of small magnitude $\left(\mathrm{M}_{\mathrm{L}}<2.5\right)$ and highly clustered within the SAMBA array beneath the area of highest topography. In the vicinity of Mt. Cook, a bulge in the seismicity occurs with its maximum centered beneath the Main Divide Fault Zone at depths of $6 \mathrm{~km}$ (transect 6 of Figure 4). The same depth has been identified by Stern et al. [2007] as the upper boundary of a low P-wave velocity zone that extends downward to depths of $30 \mathrm{~km}$. A similar structure can be seen just south of Mt. Cook in the crustal seismic reflection profile of Long et al. [2003]. Long et al. [2003] describe an "antifold" of $15 \mathrm{~km}$ half wavelength with its' crest at $3 \mathrm{~km}$ depth and imaged to 10 $\pm 2 \mathrm{~km}$ depth. They interpreted that this structure accommodated $1.8 \mathrm{~km}(=12 \%)$ horizontal crustal shortening in less than $1 \mathrm{Myr}$ at current GPS strain rates. At the southwestern boundary of the SAMBA network, the seismically active zone is narrow and earthquake depths increase rapidly in the direction perpendicular to the strike of the Alpine Fault.

[58] A depth of the seismogenic zone of $12 \pm 2 \mathrm{~km}$ has been suggested from seismicity studies in the central Southern Alps [Leitner et al., 2001; Reyners, 1988] and 5$12 \mathrm{~km}$ has been suggested as the locking depth based on GPS measurements [Beavan et al., 1999, 2004; Wallace et al., 2007]. We find that the seismogenic depth varies across the Southern Alps with depths of $10 \pm 2 \mathrm{~km}$ beneath the surface trace of the Alpine Fault and $8 \pm 2 \mathrm{~km}$ within $20 \mathrm{~km}$ distance of the fault. At distances larger than $20 \mathrm{~km}$, it increases in depth to a thickness of $15 \pm 2 \mathrm{~km}$, similar to the shape of the high-resistivity zone. New earthquake hypocenter locations recorded by an additional short-term deployment of 12 stations in the area between the Wanganui and the Whataroa Rivers during January and May 2010 indicate that our results for hypocenter depths along SIGHT transect T1 (Figure 5) and the depth profiles 
a)

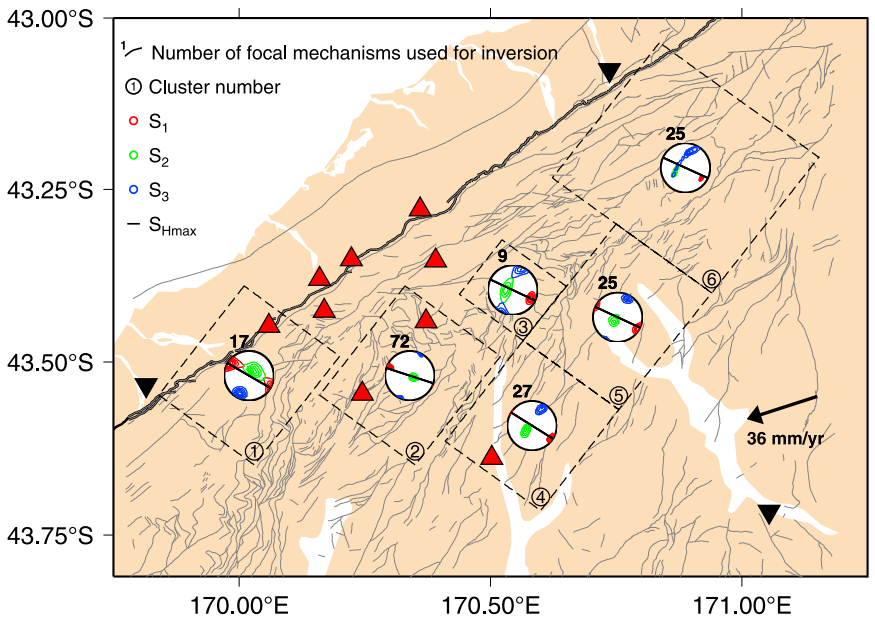

b)

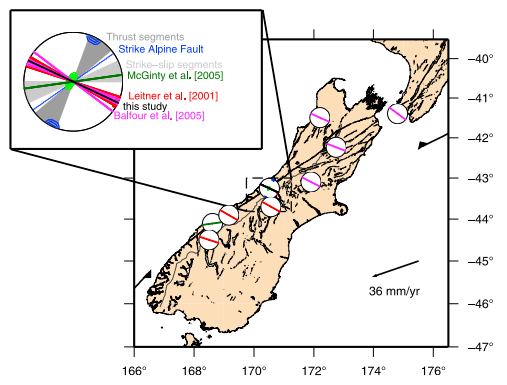

Figure 10. (a) Principal stress directions $\left(\mathrm{S}_{1}<\mathrm{S}_{2}<\mathrm{S}_{3}\right)$ and maximum horizontal compressive stress $\left(\mathrm{S}_{\mathrm{Hmax}}\right)$ derived from focal mechanism inversion of groups of events as shown in Figure 9. The number on top of the stereogram indicates the number of focal mechanism solutions inverted for the principal stresses. The encircled number in the dashed rectangles gives the cluster number for which results are listed in Table 4. (b) Stress inversion results of the 211 focal mechanism solutions in comparison with the maximum horizontal stress directions derived in other studies for different regions of northern and central South Island. The inset shows a summary of the stress directions in comparison to the strike of the Alpine Fault (blue) and its respective thrust and strike-slip segments (light and dark grey).

1-3 (Figure 4) are robust and slightly overestimate the earthquake depths.

[59] The lateral variation in the near-surface resistivity structure correlates well with the distribution of microseismicity. Our results show that no earthquakes are generated in the conductive zone $<100 \Omega \mathrm{m}$ at depths greater than $20 \mathrm{~km}$. The material is either too hot, too fluid-saturated or too weak (or a combination of all three) to produce earthquakes of recordable size. Earthquakes are generated in the high-resistivity zones adjacent to or above the lowresistivity regions. We find that clustering of the events is strongest where the resistivity contrast is highest. A similar distribution of microearthquakes has been observed for the San Andreas Fault where resistivity measurements revealed a fault zone conductor with resistivities $<10 \Omega \mathrm{m}$ [Unsworth and Bedrosian, 2004]. The microseismicity

Table 4. Principal Stress Directions (Trend/Plunge) and Maximum Horizontal Compressive Stress of All Events in One Region as Shown in Figure $10 \mathrm{a}^{\mathrm{a}}$

\begin{tabular}{cccccr}
\hline Cluster & $\mathrm{S}_{1}$ & $\mathrm{~S}_{2}$ & \multicolumn{1}{c}{$\mathrm{S}_{3}$} & \multicolumn{1}{c}{$\mathrm{R}$} & $\mathrm{S}_{\text {Hmax }}$ \\
\hline 1 & $121.1^{\circ} / 8.8^{\circ}$ & $65.0^{\circ} / 65.9^{\circ}$ & $27.4^{\circ} / 22.2^{\circ}$ & $0.25_{-0.250}^{+0.303}$ & $118 \pm 16.8^{\circ}$ \\
2 & $115.0^{\circ} / 13.7^{\circ}$ & $115.7^{\circ} / 76.3^{\circ}$ & $25.0^{\circ} / 0.0^{\circ}$ & $0.15 \pm 0.09$ & $115 \pm 10.2^{\circ}$ \\
3 & $115.0^{\circ} / 20.4^{\circ}$ & $56.6^{\circ} / 67.8^{\circ}$ & $23.2^{\circ} / 8.3^{\circ}$ & $0.77_{-0.321}^{+0.211}$ & $114 \pm 16.6^{\circ}$ \\
4 & $123.7^{\circ} / 9.4^{\circ}$ & $53.8^{\circ} / 63.3^{\circ}$ & $29.1^{\circ} / 24.8^{\circ}$ & $0.69 \pm 0.239$ & $122 \pm 13.1^{\circ}$ \\
5 & $119.2^{\circ} / 5.4^{\circ}$ & $49.1^{\circ} / 74.6^{\circ}$ & $27.7^{\circ} / 14.4^{\circ}$ & $0.47 \pm 0.306$ & $118 \pm 14.5^{\circ}$ \\
6 & $123.7^{\circ} / 24.4^{\circ}$ & $67.2^{\circ} / 52.0^{\circ}$ & $22.1^{\circ} / 27.4^{\circ}$ & $0.89_{-0.097}^{+0.097}$ & $122 \pm 12.0^{\circ}$ \\
\hline
\end{tabular}

${ }^{\mathrm{a}} \mathrm{R}=\left(\mathrm{S}_{1}-\mathrm{S}_{2}\right) /\left(\mathrm{S}_{1}-\mathrm{S}_{3}\right)$ specifies the stress ratio. The uncertainty in $\mathrm{R}$ is estimated from the upper and lower bounds given by the $10 \%$ and $90 \%$ percentiles of the posterior probability density function. The posterior distribution is skewed near values of 0 and 1 because the R-value is confined to lie within these limits. 
Table 5. Maximum Compressive Stress $S_{1}$ (Trend/Plunge) or Maximum Horizontal Compressive Stress $\mathrm{S}_{\mathrm{Hmax}}$, With Uncertainties if Reported, for South Island Measurements Obtained in Previous Studies

\begin{tabular}{lccl}
\hline $\mathrm{S}_{\mathrm{Hmax}}$ or $\mathrm{S}_{1}$ & Region & Method $^{\mathrm{a}}$ & \multicolumn{1}{c}{ Reference } \\
\hline $300^{\circ} / 30^{\circ}$ & northern Marlborough & IPP & McGinty et al. $[2000]$ \\
$118^{\circ} / 6^{\circ}$ & southern Marlborough & IPP & McGinty et al. $[2000]$ \\
$299 \pm 17^{\circ}$ & Marlborough & FMI & Balfour et al. $[2005]$ \\
$291^{\circ}$ & Lake Tennyson & FMI & Balfour et al. $[2005]$ \\
$107 \pm 6^{\circ}$ & west of Arthur's Pass & TT+GPS & Pearson et al. $[1995]$ \\
$116 \pm 9^{\circ}$ & east of Arthur's Pass & TT+GPS & Pearson et al. $[1995]$ \\
$119 \pm 17^{\circ}$ & north of Mt. Cook & FMI & Leitner et al. $[2001]$ \\
$121 \pm 36^{\circ}$ & south of Mt. Cook & TT & Blick et al. $[1989]$ \\
$84^{\circ} / 16^{\circ}$ & Jackson Bay & IPP & McGinty et al. $[2005]$ \\
\hline
\end{tabular}

${ }^{\mathrm{a}}$ Methods are IPP, inversion of P-wave polarities; FMI, focal mechanism inversion; TT, triangularization/trilateration.

occurs below or adjacent to these zones in high-resistivity zones. Similar distributions of earthquakes on the boundary between high and low-resistivity regions have been observed for microearthquakes [Ichiki et al., 1999], swarms [Tank et al., 2003] and large earthquakes and their aftershocks [Eberhart-Phillips et al., 1990; Kasaya et al., 2002]. Takeda et al. [1999] observed the occurrence of earthquakes at shallow depths in areas of low water saturation and high crack density surrounded by areas of high saturation. They attributed the generation of earthquakes to fluid flow into cracks in rocks with a low degree of saturation. Kato et al. [2010] observed intense seismic activity at shallow depths above a high-velocity body of intruded diorite, causing high heat flow and the release of fluids that invaded and fractured the overlying rock.

[60] We suggest that extensive fracturing occurs in the central Southern Alps due to ascending fluids and that the Main Divide Fault Zone [Cox et al., 1997] and other backthrust faults act as active fluid conduits. A resistivity model by Wannamaker et al. [2009] for a transect crossing the Marlborough Fault System shows similar low resistivity regions $<100 \Omega \mathrm{m}$ at depths greater than $10 \mathrm{~km}$ beneath the Awatere and Clarence faults. As observed for the central Southern Alps, the crustal seismicity in this region is also confined to high resistivity bodies. Wannamaker et al. [2009] attribute this seismicity to fault fracture meshes created by the upwards migration of fluids from the subducting slab of the Pacific plate.

[61] Notably, all of the largest, more recent earthquakes (noted in Table 1) in the central South Island occurred southeast of the Alpine Fault. These events occurred at the lower end of the earthquake depth-distribution, presumably near the base of the seismogenic zone. If we assume that the hypocenter locations determined in this study reflect the vertical extent of the seismogenic zone, then the seismogenic depth reaches a maximum at distances $>25 \mathrm{~km}$ perpendicular to the surface trace of the Alpine Fault. At these distances, the seismogenic zone has almost twice the thickness of the seismogenic depth near the Alpine Fault. In other words, earthquakes generated in this area can potentially be larger than further west due to the vertical extent of the seismogenic zone.

[62] The microearthquake locations in the region bounded by the Wanganui and the Whataroa River reveal in more detail the aseismic zone noted previously [e.g., Leitner et al., 2001]. Within the vicinity of the Alpine Fault $(<10 \mathrm{~km})$, the seismicity does not change significantly along strike. The area with reduced seismicity extends from 15 to $30 \mathrm{~km}$ of the fault and is bounded by the cluster c (Figure 3c). The distribution of earthquakes is symmetric around this gap, but the number of events is not (Figures 3a and $3 \mathrm{c}$ ). Earthquakes at the northeastern boundary of the low-seismicity region are larger in magnitude and more frequent than at the southwestern limit. The density of mapped faults in the aseismic region is reduced, too. The detection threshold of events at the southwestern limit of this area is better than to the northeast due to the station distribution. If similar sized events occurred at the southern boundary, they would have been recorded by the SAMBA stations. The low-seismicity area is characterized by a lowattenuation block in the attenuation model of EberhartPhillips et al. [2008]. Changes in the geology with flatlying sequences of schist and semi-schist occur in this region, as noted by Leitner et al. [2001]. However, there is no obvious correlation between bedding dip and the distribution of earthquakes. The remnants of a major ice plateau are located in this area, but the plateau's exact location does not coincide with the observed distribution of events. However, the seismicity gap could be associated with seismic quiescence following pronounced activity associated with localized bending and uplift resulting from rapid ice loss since the end of last glacial period $14000 \mathrm{yr}$ ago [Suggate, 1990]. On the other hand, if that area forms a seismic gap, it could be a seismic gap of the second kind [Mogi, 1979], which is characterized by quiescence in smaller magnitude activity before a large earthquake. If this is the case, the rupture area amounts to at least $\sim 300 \mathrm{~km}^{2}$ corresponding to a magnitude 6.5 earthquake. Since similarly large earthquakes have occurred at some distance from the Alpine Fault, further detailed studies in this region are necessary.

[63] The magnitudes of the recorded earthquakes in the study area span $-0.3 \leq \mathrm{M}_{\mathrm{L}} \leq 4.2$ but are smaller in the region of highest uplift, where the upper magnitude threshold is $\mathrm{M}_{\mathrm{L}} 2.5$. Based on our magnitude scale, we deduce that high-frequency waves ( $>10 \mathrm{~Hz}$ ) are attenuated more than twice as much as low-frequency waves $(\mathrm{f}<5 \mathrm{~Hz})$. The frequency-independent attenuation coefficient used in routine magnitude determination New Zealand-wide thus underestimates the local magnitude if the distance between the earthquake source and the recording station is small $(<70$ $\mathrm{km})$.

[64] Focal mechanism solutions for microearthquakes recorded in this study indicate predominantly strike-slip faulting. For small to intermediate size earthquakes the ratio of reverse to strike-slip mechanism reaches $1: 2$ as expected from the direction of relative plate motion in relation to the strike of the Alpine Fault. At larger magnitudes $\left(\mathrm{M}_{\mathrm{W}}>5.4\right)$ this ratio persists. Stress inversion of our focal mechanisms reveals a homogeneous strike-slip stress field in the central Southern Alps except for localized topographic modifications. The direction of maximum horizontal compressive stress is $\mathrm{S}_{\mathrm{Hmax}}=115 \pm 10^{\circ}$. The resulting angle between the average strike of the Alpine Fault and $\mathrm{S}_{\mathrm{Hmax}}$ is $59^{\circ}$ as characteristic of a weak fault. However, small-scale thrust segments are oriented at angles 
Table A1. Site Locations and Borehole Depths of All SAMBA Stations ${ }^{\text {a }}$

\begin{tabular}{|c|c|c|c|c|c|}
\hline Station & Location & Latitude (deg) & Longitude (deg) & Altitude (m) & Depth (m) \\
\hline COSA & Cook Saddle & -43.448 & 170.060 & 377 & 1.40 \\
\hline EORO & End of Road & -43.426 & 170.169 & 233 & 1.35 \\
\hline MTFO & Mount Fox & -43.512 & 170.003 & 1216 & 2.00 \\
\hline WHAT & Whataroa Quarry & -43.279 & 170.360 & 95 & 61.00 \\
\hline WHYM & Whymper Hut & -43.441 & 170.371 & 906 & 1.30 \\
\hline POCR & Potter's Creek & -43.352 & 170.223 & 185 & 46.00 \\
\hline LABE & De la Beche & -43.546 & 170.245 & 1590 & 2.15 \\
\hline GOVA & Godley Valley & -43.639 & 170.503 & 814 & 1.95 \\
\hline FRAN & Carnavan's Knob & -43.380 & 170.160 & 124 & 98.00 \\
\hline REYN & Reynold's Creek & -43.353 & 170.391 & 1310 & 1.20 \\
\hline
\end{tabular}

${ }^{a}$ Altitude and depth refer to the top of the borehole.

of $65^{\circ}-95^{\circ}$ and strike-slip segments are oriented at angles ranging between $25^{\circ}$ and $50^{\circ}$ to $\mathrm{S}_{\mathrm{Hmax}}$, implying that shallow segmentation of the Alpine Fault takes place on favorably oriented structures.

\section{Appendix A: SAMBA Station Locations}

[65] To supplement the New Zealand national station network in the central section of the Southern Alps, the Southern Alps Microearthquake Borehole Array (SAMBA) comprising ten short-period seismometers was installed between November 2008 and June 2009 (Table A1).

\section{Appendix B: Non-Linear Hypocenter Determination}

[66] In this study earthquake locations were obtained using NonLinLoc by A. Lomax [Lomax et al., 2000]. The NonLinLoc algorithm is based on the probabilistic nonlinear inversion approach of Tarantola and Valette [1982] and determines the posterior probability density function (PDF) of each hypocenter from the synthetic travel-times of P- and S-waves for each cell on a grid. The obtained PDF solutions (using the "Oct-Tree" search method [Lomax et al., 2000] on a grid of $1 \mathrm{~km}$ node spacing orientated at a $55^{\circ}$ angle with respect to the Alpine Fault) represent the uncertainty of the earthquake location as a volume of irregular form, which reflects uncertainties due to the network-event geometry, arrival-time reading errors and calculated travel-time errors. The final earthquake hypocenter is selected as the point of maximum likelihood in the PDF solution. Gaussian uncertainties are assumed for the phase arrival-time observations and the travel-time calculation errors [Tarantola and Valette, 1982].

\section{Appendix C: Travel-Time Residual Analysis}

[67] The travel-time residuals were analyzed for all earthquakes between 24 March and December 2009, when the SAMBA station network was in its final state and recorded continuously.

[68] Assuming that, on average, phases are correctly picked, the mean and the standard deviation of the traveltime residuals of all events at one station (Table $\mathrm{C} 1$ ) can be used to find outliers and trends in the data set. Events with large residuals were manually checked. The mean of the travel-time residuals $\mu=\sigma^{\text {model }}$ for one station indicates inaccuracies in the applied 1D-velocity model. The standard deviation of the travel-time residuals $\sigma=\sigma^{\text {reading }}$ indicates the typical reading error. A comparison of the travel-time residuals for impulsive and emergent $\mathrm{P}$ - and $\mathrm{S}$ waves at all stations shows that for the majority of stations the standard deviation for impulsive and emergent phase onsets is similar; $\sigma_{\mathrm{I}} \sim \sigma_{\mathrm{E}}$. In other words, those phase arrivals can be treated as one population. However, the stations themselves do not have common variances. Note

Table C1. Post-Weighting Mean and Standard Deviations of the Travel-Time Residuals for Impulsive and Emergent P- and S-Phase Arrival Times for All Stations ${ }^{\mathrm{a}}$

\begin{tabular}{|c|c|c|c|c|c|c|c|c|}
\hline Station & $\mu_{\mathrm{IP}} \pm \sigma_{\mathrm{IP}}$ & $\mu_{\mathrm{EP}} \pm \sigma_{\mathrm{EP}}$ & $\mu_{\mathrm{IS}} \pm \sigma_{\mathrm{IS}}$ & $\mu_{\mathrm{ES}} \pm \sigma_{\mathrm{ES}}$ & IP & EP & IS & ES \\
\hline FRAN & $0.03 \pm 0.06$ & $0.04 \pm 0.09$ & $0.02 \pm 0.11$ & $-0.01 \pm 0.15$ & 421 & 401 & 315 & 471 \\
\hline REYN & $0.11 \pm 0.08$ & $0.04 \pm 0.11$ & $-0.00 \pm 0.09$ & $0.01 \pm 0.11$ & 8 & 610 & 88 & 446 \\
\hline WHAT & $0.02 \pm 0.13$ & $0.02 \pm 0.15$ & $-0.10 \pm 0.18$ & $-0.07 \pm 0.18$ & 419 & 330 & 185 & 449 \\
\hline LABE & $-0.03 \pm 0.07$ & $-0.04 \pm 0.14$ & $-0.06 \pm 0.16$ & $-0.06 \pm 0.13$ & 522 & 232 & 460 & 278 \\
\hline MTFO & $-0.02 \pm 0.10$ & $-0.00 \pm 0.11$ & $-0.01 \pm 0.16$ & $-0.04 \pm 0.19$ & 322 & 357 & 177 & 507 \\
\hline EORO & $-0.03 \pm 0.07$ & $-0.04 \pm 0.08$ & $-0.10 \pm 0.08$ & $-0.13 \pm 0.12$ & 406 & 478 & 245 & 479 \\
\hline COSA & $0.03 \pm 0.12$ & $0.04 \pm 0.09$ & $0.16 \pm 0.15$ & $0.13 \pm 0.93$ & 75 & 304 & 67 & 331 \\
\hline POCR & $0.16 \pm 0.09$ & $0.16 \pm 0.09$ & $0.14 \pm 0.25$ & $0.12 \pm 0.14$ & 345 & 313 & 71 & 444 \\
\hline WHYM & $-0.01 \pm 0.08$ & $-0.00 \pm 0.11$ & $0.01 \pm 0.10$ & $0.02 \pm 0.12$ & 671 & 288 & 358 & 529 \\
\hline GOVA & $-0.03 \pm 0.08$ & $-0.00 \pm 0.10$ & $0.03 \pm 0.08$ & $0.01 \pm 0.31$ & 699 & 195 & 614 & 333 \\
\hline FOZ & $0.01 \pm 0.10$ & $0.01 \pm 0.10$ & $-0.02 \pm 0.18$ & $-0.04 \pm 0.16$ & 96 & 200 & 108 & 267 \\
\hline RPZ & $-0.06 \pm 0.09$ & $-0.04 \pm 0.11$ & $0.04 \pm 0.09$ & $0.05 \pm 0.10$ & 130 & 117 & 156 & 152 \\
\hline WVZ & $-0.08 \pm 0.14$ & $-0.08 \pm 0.14$ & $-0.05 \pm 0.12$ & $-0.13 \pm 0.22$ & 236 & 84 & 196 & 88 \\
\hline
\end{tabular}

${ }^{\text {a }}$ The mean $\mu$ represents the model-error $\sigma^{\text {model }}$ of the $1 \mathrm{D}$-velocity model for one station. The standard deviation $\sigma$ indicates the mean reading error $\sigma^{\text {reading }}$. The numbers give total numbers of $\mathrm{P}$ and $\mathrm{S}$-phases recorded at the station. 
that the number of $\mathrm{P}$ and $\mathrm{S}$ phases for most stations are almost equal.

[69] Acknowledgments. We thank Mike Hasting and Mark Henderson for help with establishing the SAMBA network. We are grateful to Richard Arnold and Stephen Bannister for help with software and to Philip Wannamaker for providing his resistivity model. We acknowledge the New Zealand GeoNet project and its sponsors the Earthquake Commission (EQC), GNS Science and Land Information New Zealand (LINZ) for providing earthquake data used in this study. This research is funded by the New Zealand Marsden Fund and the New Zealand International Doctoral Research Scholarship.

\section{References}

Abercrombie, R. (1998), A summary of attenuation measurements from borehole recordings of earthquakes: The $10 \mathrm{~Hz}$ transition problem, Pure Appl. Geophys., 153, 475-487.

Abercrombie, R., T. Webb, R. Robinson, P. McGinty, R. Beavan, and J. Mori (2000), The enigma of the Arthur's Pass, New Zealand, earthquake: 1. Reconciling a variety of data for an unusual earthquake sequence, J. Geophys. Res., 105, 16,119-16,137.

Adams, J. (1980), Paleoseismicity of the Alpine fault seismic gap, New Zealand, Geology, 8, 72-76.

Anderson, H., and W. Webb (1994), New Zealand seismicity: Patterns revealed by the upgraded National Seismograph Network, N. Z. J. Geol. Geophys., 37, 477-493.

Anderson, H., W. Webb, and J. Jackson (1993), Focal mechanisms of large earthquakes in the South Island of New Zealand: Implications for the accommodation of Pacific-Australia plate motion, Geophys. J. Int., 115, 1032-1054.

Árnadóttir, T., J. Beavan, and C. Pearson (1995), Deformation associated with the 18 June 1994 Arthur's Pass earthquake, New Zealand, N. Z. J. Geol. Geophys., 38, 553-558.

Arnold, R., and J. Townend (2007), A Bayesian approach to estimating tectonic stress from seismological data, Geophys. J. Int., 170, 1336-1356.

Balfour, N. J., M. K. Savage, and J. Townend (2005), Stress and crustal anisotropy in Marlborough, New Zealand: Evidence for low fault strength and structure-controlled anisotropy, Geophys. J. Int., 163, 1073-1086.

Beavan, J., et al. (1999), Crustal deformation during 1994-1998 due to oblique continental collision in the central Southern Alps, New Zealand, and implications for seismic potential of the Alpine fault, J. Geophys Res., 104, 25,233-25,255.

Beavan, J., D. Matherson, P. Denys, M. Denham, T. Herring, B. Hager, P. Molnar, and D. Walcott (2004), A vertical deformation profile across the Southern Alps, New Zealand, from 3.5 years of continuous GPS data in Proceedings of the workshop: The State of GPS Vertical Positioning Precision: Separation of Earth Processes by Space Geodesy, Cah. Cent Eur. Géodyn. Séismol., vol. 23, pp. 111-123, Cent. for Eur. Géodyn. and Séismol., Luxembourg.

Beavan, J., P. Denys, M. Denham, B. Hager, T. Herring, and P. Molnar (2010), Distribution of present-day vertical deformation across the Southern Alps, New Zealand, from 10 years of GPS data, Geophys. Res. Lett., 37, L16305, doi:10.1029/2010GL044165.

Berryman, K., and P. Villamor (2004), Surface rupture of the Poulter Fault in the 1929 March 9 Arthur's Pass earthquake, and redefinition of the Kakapo Fault, New Zealand, N. Z. J. Geol. and Geophys., 47, 341-351.

Berryman, K., S. Beanland, A. Cooper, H. Cutten, R. Norris, and P. Wood (1992), The Alpine Fault, New Zealand: Variation in Quaternary structural style and geomorphic expression, Ann. Tectonicae, 6, 126-163.

Blick, G., S. Read, and P. Hall (1989), Deformation monitoring of the Ostler fault zone, South Island, New Zealand, Tectonophysics, 167 329-339.

Brikké, N. E. A. (2010), 3D seismic travel-time tomography of the central South Island, New Zealand, MSc thesis, Victoria Univ. of Wellington, Wellington, New Zealand

Caldwell, J. G., and C. Frohlich (1975), Microearthquake study of the Alpine fault zone near Haast, South Island, New Zealand, Bull. Seismol. Soc. Am., 65, 1097-1104.

Cande, S. C., and J. M. Stock (2004), Pacific-Antarctic-Australia motion and the formation of the Macquarie Plate, Geophys. J. Int., 157, 399-414

Cande, S., and J. Stock (2005), Cenozoic reconstructions of the AustraliaNew Zealand-South Pacific sector of Antarctica, in The Cenozoic Southern Ocean: Tectonics, Sedimentation and Climate Change Between Australia and Antarctica, Geophys. Monogr. Ser., vol. 151, edited by N. F. Exon, J. P. Kennett, and M. J. Malone, pp. 5-18, AGU, Washington, D. C.

Clarke, D. (2008), Velocity modelling and earthquake relocation in the Rotorua and Kawerau geothermal areas, Taupo Volcanic Zone, New
Zealand, MSc thesis, Victoria Univ. of Wellington, Wellington, New Zealand

Cooper, A. (1980), Retrograde alteration of chromian kyanite in metachert and amphibolite whiteschist from the Southern Alps, New Zealand, with implications for uplift on the Alpine Fault, Contrib. Mineral. Petrol., 75, 153-164.

Cowan, H. A. (1991), The North Canterbury earthquake of September 1, 1888, J. R. Soc. N. Z., 21, 1-12.

Cowan, H., A. Nicol, and P. Tonkin (1996), A comparison of historical and paleoseismicity in a newly formed fault zone and a mature fault zone, North Canterbury, New Zealand, J. Geophys. Res., 101, 6021-6036.

Cox, S., and R. Findlay (1995), The Main Divide Fault Zone and its role in formation of the Southern Alps, New Zealand, N. Z. J. Geol. Geophys., 38, 489-499.

Cox, S., and R. Sutherland (2007), Regional geological framework of South Island, New Zealand, and its significance for understanding the active plate boundary, in $A$ Continental Plate Boundary: Tectonics at South Island, New Zealand, Geophys. Monogr. Ser., vol. 175, edited by D. Okaya, T. Stern, and F. Davey, pp. 19-46, AGU, Washington, D. C. Cox, S., D. Craw, and C. Chamberlain (1997), Structure and fluid migration in a late Cenozoic duplex system forming the Main Divide in the central Southern Alps, New Zealand, N. Z. J. Geol. Geophys., 40, 359-373.

Davey, F., et al. (1998), Preliminary results from a geophysical study across a modern, continent-continent collisional plate boundary-The Southern Alps, New Zealand, Tectonophysics, 288, 221-235.

Deichmann, N. (2006), Local magnitude, a moment revisited, Bull. Seismol. Soc. Am., 96, 1267-1277.

De Mets, C., R. G. Gordon, D. F. Argus, and S. Stein (1994), Effect of recent revisions to the geomagnetic reversal timescale on estimates of current plate motions, Geophys. Res. Lett., 21, 2191-2194.

Doser, D. I., T. H. Webb, and D. E. Maunder (1999), Source parameters of large historical (1918-1962) earthquakes, South Island, New Zealand, Geophys. J. Int., 139, 769-794.

Dziewonski, A., G. Ekstrom, and N. Maternovskaya (1999), Centroidmoment tensor solutions for October-December, 1998, Phys. Earth Planet. Inter., 115, 1-16.

Eberhart-Phillips, D. (1995), Examination of seismicity in the central Alpine Fault region, South Island, New Zealand, N. Z. J. Geol. Geophys., 38, 571-578.

Eberhart-Phillips, D., and S. Bannister (2002), Three-dimensional crustal structure in the Southern Alps region of New Zealand from inversion of local earthquake and active source data, J. Geophys. Res., 107(B10), 2262, doi:10.1029/2001JB000567.

Eberhart-Phillips, D., V. Labson, W. Stanley, A. Michael, and B. Rodriguez (1990), Preliminary velocity and resistivity models of the Loma Prieta earthquake region, Geophys. Res. Lett., 17, 1235-1238.

Eberhart-Phillips, D., M. Chadwick, and S. Bannister (2008), Threedimensional attenuation structure of central and southern South Island, New Zealand, from local earthquakes, J. Geophys. Res., 113, B05308, doi:10.1029/2007JB005359.

Eiby, G. A. (1971), Seismic regions of the South Island of New Zealand, Trans. R. Soc. N. Z. Earth Sci., 8, 29-39.

Evison, F. F. (1971), Seismicity of the Alpine Fault, New Zealand, in Recent Crustal Movements, R. Soc. N. Z. Bull., 9, 161-165.

Fialko, Y., L. Rivera, and H. Kanamori (2005), Estimate of differential stress in the upper crust from variations in topography and strike along the San Andreas fault, Geophys. J. Int., 160, 527-532.

Gledhill, K., R. Robinson, T. Webb, R. Abercrombie, J. Beavan, J. Cousins, and D. Eberhart-Phillips (2000), The $\mathrm{M}_{\mathrm{W}}$ 6.2 Cass, New Zealand, earthquake of 24 November 1995: Reverse faulting in a strike-slip region, $N$. Z. J. Geol. Geophys., 43, 255-270.

Grapes, R., T. Little, and G. Downes (1998), Rupturing of the Awatere Fault during the 1848 October 16 Marlborough earthquake, New Zealand: Historical and present day evidence, N. Z. J. Geol. Geophys., 41, 387-399.

Hardebeck, J. (2006), Homogeneity of small-scale earthquake faulting, stress, and fault strength, Bull. Seismol. Soc. Am., 96, 1675-1688.

Hardebeck, J., and P. Shearer (2002), A new method for determining firstmotion focal mechanisms, Bull. Seismol. Soc. Am., 92, 2264-2276.

Havskov, J., and L. Ottemöller (2000), Seisan: The earthquake analysis software, report, 236 pp., Inst. of Solid Earth Phys, Univ. of Bergen, Bergen, Norway.

Hincapie, J., D. Doser, and R. Robinson (2005), Stress changes induced by earthquakes and secular stress accumulation in the Buller region, South Island, New Zealand (1929-2002), Pure Appl. Geophys., 162, 291-310. Ichiki, M., M. Mishina, T. Goto, N. Oshiman, N. Sumitomo, and H. Utada (1999), Magnetotelluric investigations for the seismically active area in Northern Miyagi Prefecture, northeastern Japan, Earth Planets Space, $51,351-362$. 
Jeffreys, H. (1973), On travel times in seismology, in Collected Papers of Sir Harold Jeffreys on Geophysics and Other Sciences, edited by H. Jeffreys, pp. 36-120, Gordon and Breach, London.

Kamp, P. J. J., P. F. Green, and S. H. White (1989), Fission track analysis reveals character of collisional tectonics in New Zealand, Tectonics, 8 , 169-195.

Kasaya, T., N. Oshiman, N. Sumitomo, M. Uyeshima, Y. Iio, and D. Uehara (2002), Resistivity structure around the hypocentral area of the 1984 Western Nagano Prefecture earthquake in central Japan, Earth Planets Space, 54, 107-118.

Kato, A., S. Sakai, T. Iidaka, T. Iwasaki, and N. Hirata (2010), Nonvolcanic seismic swarms triggered by circulating fluids and pressure fluctuations above a solidified diorite intrusion, Geophys. Res. Lett., 37, L15302, doi:10.1029/2010GL043887.

Kim, W. (1998), The $\mathrm{M}_{\mathrm{L}}$ scale in eastern North America, Bull. Seismol. Soc. Am., 88, 935-951.

Kleffman, S., F. Davey, A. Melhuish, D. Okaya, T. Stern, and SIGHT Team (1998), Crustal structure in the central South Island, New Zealand, from the Lake Pukaki seismic experiment, N. Z. J. Geol. Geophys., 41, 39-49.

Koons, P. (1987), Some thermal and mechanical consequences of rapid uplift: An example from the Southern Alps, New Zealand, Earth Planet. Sci. Lett., 86, 307-319.

Langridge, R., J. Campbell, N. Hill, V. Pere, J. Pope, J. Pettinga, B. Estrada, and K. Berryman (2003), Paleoseismology and slip rate of the Conway Segment of the Hope Faultat Greenburn Stream, South Island, New Zealand, Ann. Geophys., 46, 1119-1139.

Leitner, B., D. Eberhart-Phillips, H. Anderson, and J. L. Nabelek (2001), A focused look at the Alpine fault, New Zealand: Seismicity, focal mechanisms, and stress observations, J. Geophys. Res., 106, 2193-2220.

Little, T. A., and A. Jones (1998), Seven million years of strike-slip and related off-fault deformation, northeastern Marlborough fault system, South Island, New Zealand, Tectonics, 17, 285-302.

Little, T. A., R. Holcombe, and B. Ilg (2002), Kinematics of oblique collision and ramping inferred from microstructures and strain in middle crustal rocks, central Southern Alps, New Zealand, J. Struct. Geol., 24, 219-239.

Little, T. A., S. C. Cox, J. K. Vry, and G. Batt (2005), Variations in exhumation level and uplift rate along the oblique-slip Alpine fault, central Southern Alps, New Zealand, Geol. Soc. Am. Bull., 117, 707-723.

Lockner, D., C. Morrow, D. Moore, and S. Hickman (2011), Low strength of deep San Andreas fault gouge from SAFOD core, Nature, 472, 82-85.

Lomax, A., J. Virieux, P. Volant, and C. Berge (2000), Probabilistic earthquake location in 3D and layered models: Introduction of a MetropolisGibbs method and comparison with linear locations, in Advances in Seismic Event Location, edited by C. Thurber and N. Rabinowitz, pp. 101-134, Kluwer, Amsterdam.

Long, D., S. Cox, S. Bannister, M. Gerstenberger, and D. Okaya (2003), Upper crustal structure beneath the eastern Southern Alps and the Mackenzie Basin, New Zealand, derived from seismic reflection data, N. Z. J. Geol. Geophys., 46, 21-40.

Lund, B., and J. Townend (2007), Calculating horizontal stress orientations with full or partial knowledge of the tectonic stress tensor, Geophys. J. Int., $170,1328-1335$

McGinty, P., M. Reyners, and R. Robinson (2000), Stress directions in the shallow part of the Hikurangi subduction zone, New Zealand, from the inversion of earthquake first motions, Geophys. J. Int., 142, 339-350.

McGinty, P., R. Robinson, and T. Webb (2005), The $2001 \mathrm{M}_{\mathrm{L}} 6.2$ Jackson Bay earthquake sequence, South Island, New Zealand, N. Z. J. Geol. Geophys., 48, 315-324.

McKenzie, D. (1969), The relation between fault plane solutions for earthquakes and the directions of the principal stresses, Bull. Seismol. Soc. Am., 59, 591-601.

Mogi, K. (1979), Two kinds of seismic gaps, Pure Appl. Geophys., 117, $1172-1186$

Norris, R. J., and A. F. Cooper (1995), Origin of small-scale segmentation and transpressional thrusting along the Alpine fault, New Zealand, Geol. Soc. Am. Bull., 107, 231-240.

Norris, R. J., and A. F. Cooper (2001), Late Quaternary slip rates and slip partitioning on the Alpine Fault, New Zealand, J. Struct. Geol., 23 , $507-520$.

Norris, R., and A. Cooper (2003), Very high strains recorded in mylonites along the Alpine Fault, New Zealand: Implications for the deep structure of plate boundary faults, J. Struct. Geol., 25, 2141-2157.

Norris, R., P. Koons, and A. Cooper (1990), The obliquely-convergent plate boundary in the South Island of New Zealand: Implications for ancient collision zones, J. Struct. Geol., 12, 715-725.

Okaya, D., S. Henrys, and T. Stern (2002), Double-sided onshore-offshore seismic imaging of a plate boundary: "Super-gathers" across South Island, New Zealand, Tectonophysics, 355, 247-263.
O'Keefe, B. C. (2008), Microseismicity of the central Alpine Fault region, New Zealand, MSc thesis, Victoria Univ. of Wellington, Wellington, New Zealand.

Pearson, C., J. Beavan, D. Darby, G. Blick, and R. Walcott (1995), Strain distribution across the Australian-Pacific plate boundary in the central South Island, New Zealand, from 1992 GPS and earlier terrestrial observations, J. Geophys. Res., 100, 22,071-22,081.

Petersen, T., K. Gledhill, M. Chadwick, N. Gale, and J. Ristau (2011), The New Zealand National Seismograph Network, Seismol. Res. Lett., $82,9-20$.

Reilly, W. (1990), Geodetic analysis of motion at a convergent plate boundary, in Developments in Four-Dimensional Geodesy, pp. 139-159, Springer, Berlin.

Reyners, M. (1988), Reservoir-induced seismicity at Lake Pukaki, New Zealand, Geophys. J. R. Astron. Soc., 93, 127-135.

Reyners, M., and P. McGinty (1999), Shallow subduction tectonics in the Raukumara Peninsula, New Zealand, as illuminated by earthquake focal mechanisms, J. Geophys. Res., 104, 3025-3034.

Ristau, J. (2008), Implementation of routine regional moment tensor analysis in New Zealand, Seismol. Res. Lett., 79, 400-415.

Ristau, J. (2009), Comparison of magnitude estimates for New Zealand earthquakes: Moment magnitude, local magnitude, and teleseismic body-wave magnitude, Bull. Seismol. Soc. Am., 99, 1841-1852.

Robinson, R. (1987), Temporal variations in coda duration of local earthquakes in the Wellington region, New Zealand, Pure Appl. Geophys. $125,579-596$.

Robinson, R. (2004), Potential earthquake triggering in a complex fault network: The northern South Island, New Zealand, Geophys. J. Int., 159, 734-748.

Robinson, R., and P. McGinty (2000), The enigma of the Arthur's Pass, New Zealand, earthquake: 2. The aftershock distribution and its relation to regional and induced stress fields, J. Geophys. Res., 105, $16,139-16,150$

Rynn, J., and C. Scholz (1978), Seismotectonics of the Arthur's Pass region, South Island, New Zealand, Geol. Soc. Am. Bull., 89, 1373-1388. Scherwath, M., T. Stern, A. Melhuish, and P. Molnar (2002), Pn anisotropy and distributed upper mantle deformation associated with a continental transform fault, Geophys. Res. Lett., 29(8), 1175, doi:10.1029/ 2001GL014179.

Scherwath, M., T. Stern, F. Davey, D. Okaya, W. Holbrook, R. Davies, and S. Kleffmann (2003), Lithospheric structure across oblique continental collision in New Zealand from wide-angle $\mathrm{P}$ wave modeling, J. Geophys. Res., 108(B12), 2566, doi:10.1029/2002JB002286.

Scholz, C. H., J. M. W. Rynn, R. W. Weed, and C. Frohlich (1973), Detailed seismicity of the Alpine Fault zone and Fiordland region, New Zealand, Geol. Soc. Am. Bull., 84, 3297-3316.

Shi, Y., R. Allis, and F. Davey (1996), Thermal modeling of the Southern Alps, New Zealand, Pure Appl. Geophys., 146, 469-501.

Sibson, R. (1984), Roughness at the base of the seismogenic zone: Contributing factors, J. Geophys. Res., 89, 5791-5799.

Sibson, R. H., S. White, and B. Atkinson (1979), Fault rock distribution and structure within the Alpine Fault Zone: A preliminary account, in The Origin of the Southern Alps, Bull. R. Soc. N. Z., 18, 55-65.

Sibson, R. H., S. H. White, and B. K. Atkinson (1981), Structure and distribution of fault rocks in the Alpine Fault Zone, New Zealand, in Thrust and Nappe Tectonics, Geol. Soc. Spec. Publ., 9, 197-210.

Smith, E., T. Stern, and B. O'Brien (1995), A seismic velocity profile across the central South Island, New Zealand, from explosion data, N. Z. J. Geol. Geophys., 38, 565-570.

Stern, T., S. Kleffmann, D. Okaya, M. Scherwath, and S. Bannister (2001) Low seismic-wave speeds and enhanced fluid pressure beneath the Southern Alps of New Zealand, Geology, 29, 679-682.

Stern, T., S. Kleffmann, M. Scherwath, S. Henrys, and F. Davey (2007) Geophysical exploration and dynamics of the Alpine fault zone, in $A$ Continental Plate Boundary: Tectonics at South Island, New Zealand, Geophys. Monogr. Ser., vol. 175, edited by D. Okaya, T. Stern, and F. Davey, pp. 207-233, AGU, Washington, D. C.

Suggate, R. (1990), Late Pliocene and Quaternary glaciations of New Zealand, Quat. Sci. Rev., 9, 175-197.

Sutherland, R., K. Berryman, and R. Norris (2006), Quaternary slip rate and geomorphology of the Alpine fault: Implications for kinematics and seismic hazard in southwest New Zealand, Geol. Soc. Am. Bull., 118 , 464-474.

Sutherland, R., et al. (2007), Do great earthquakes occur on the Alpine fault in central South Island, New Zealand?, in A Continental Plate Boundary Tectonics at South Island, New Zealand, Geophys. Monogr. Ser., vol. 175, edited by D. Okaya, T. Stern, and F. Davey, pp. 235-251, AGU, Washington, D. C. 
Takeda, J., Y. Iio, Y. Kobayashi, K. Yamamoto, H. Sato, S. Ohmi, H. Ito, R. Ikeda, and E. Yamamoto (1999), The relationship between seismicity and fluid existing in the crust inferred from $\mathrm{Vp} / \mathrm{Vs}$ ratio, J. Seismol. Soc. Jpn., 51, 419-430.

Tank, S., Y. Honkura, Y. Ogawa, N. Oshiman, M. Tunçer, M. Matsushima, C. Çelik, E. Tolak, and A. Istkara (2003), Resistivity structure in the western part of the fault rupture zone associated with the 1999 Izmit earthquake and its seismogenic implication, Earth Planets Space, 55 437-442.

Tarantola, A., and B. Valette (1982), Inverse problems = quest for information, J. Geophys., 50, 150-170.

Townend, J. (1999), Heat flow through the west coast, South Island, New Zealand, N. Z. J. Geol. Geophys., 42, 21-32.

Townend, J., and M. Zoback (2001), Implications of earthquake foca mechanisms for the frictional strength of the San Andreas fault system, Geol. Soc. Spec. Publ., 186, 13-21.

Townend, J., and M. Zoback (2004), Regional tectonic stress near the San Andreas fault in central and southern California, Geophys. Res. Lett., 31, L15S11, doi:10.1029/2003GL018918

Townend, J., R. Sutherland, and V. Toy (2009), Deep Fault Drilling Project Alpine Fault, New Zealand, Sci. Drill., 8, 75-82.

Toy, V., D. Craw, A. Cooper, and R. Norris (2010), Thermal regime in the central Alpine Fault zone, New Zealand: Constraints from microstructures, biotite chemistry and fluid inclusion data, Tectonophysics, 485 , 178-192.

Uhrhammer, R., and E. Collins (1990), Synthesis of Wood-Anderson seismograms from broadband digital records, Bull. Seismol. Soc. Am. $80,702-716$.

Unsworth, M., and P. A. Bedrosian (2004), On the geoelectric structure of major strike-slip faults and shear zones, Earth Planets Space, 56, 1177-1184

Van Avendonk, H., W. Holbrook, D. Okaya, J. Austin, F. Davey, and T. Stern (2004), Continental crust under compression: A seismic refraction study of South Island Geophysical Transect I, South Island, New Zealand, J. Geophys. Res., 109, B06302, doi:10.1029/2003JB002790.
Vry, J., R. Powell, K. Golden, and K. Petersen (2009), The role of exhumation in metamorphic dehydration and fluid production, Nat. Geosci., 3 , 31-35.

Walcott, R. I. (1998), Modes of oblique compression: Late Cenozoic tectonics of the South Island of New Zealand, Rev. Geophys., 36, 1-26.

Wallace, L., J. Beavan, R. McCaffrey, K. Berryman, and P. Denys (2007), Balancing the plate motion budget in the South Island, New Zealand using GPS, geological and seismological data, Geophys. J. Int., 168, 332-352.

Walsh, D., R. Arnold, and J. Townend (2009), A Bayesian approach to determining and parametrizing earthquake focal mechanisms, Geophys. J. Int., 176, 235-255.

Wannamaker, P. E., G. R. Jiracek, J. A. Stodt, T. G. Caldwell, V. M. Gonzalez, J. D. McKnight, and A. D. Porter (2002), Fluid generation and pathways beneath an active compressional orogen, the New Zealand Southern Alps, inferred from magnetotelluric data, J. Geophys. Res., 107(B6), 2117, doi:10.1029/2001JB000186.

Wannamaker, P. T. Caldwell, G. Jiracek, V. Maris, G. Hill, Y. Ogawa, H. Bibby, S. Bennie, and W. Heise (2009), Fluid and deformation regime of an advancing subduction system at Marlborough, New Zealand, Nature, 460, 733-736.

Wellman, H. (1953), Data for the study of recent and Late Pleistocene faulting in the South Island of New Zealand, N. Z. J. Sci. Technol., $34 B, 270-288$.

Wells, A., and J. Goff (2007), Coastal dunes in Westland, New Zealand, provide a record of paleoseismic activity on the Alpine fault, Geology, $35,731-734$

Wells, A., M. D. Yetton, R. P. Duncan, and G. H. Stewart (1999), Prehistoric dates of the most recent Alpine Fault earthquakes, New Zealand, Geology, 27, 995-998.

Wittlinger, G., G. Herquel, and T. Nakache (1993), Earthquake location in strongly heterogeneous media, Geophys. J. Int., 115, 759-777.

C. M. Boese, E. Smith, T. Stern, and J. Townend, School of Geography, Environment and Earth Science, Victoria University of Wellington, Wellington 6015, New Zealand. (Carolin.Boese@vuw.ac.nz) 